\title{
東太平洋海膨のオフリッジ火山は モホ遷移帯起源か?
}

\author{
海野 進* 下 司信 夫** \\ 熊 谷 英 憲***岸 本 清 行**
}

\author{
Do Off-ridge Volcanoes on the East Pacific Rise Originate \\ from the Moho Transition Zone? \\ Susumu UMINO*, Nobuo GESHI**, Hidenori KUMAGAI*** \\ and Kiyoyuki KISIMOTO**
}

\begin{abstract}
A large number of intraplate volcanoes erupted two to several hundred kilometers off the fast-spreading East Pacific Rise (EPR). These volcanoes consist of large lava fields, monogenetic volcanoes, and linear chains of monogenetic volcanoes and volcanic ridges. Large lava fields of $7-26 \mathrm{~km}^{3}$ in volume are known at $8^{\circ} \mathrm{N}, 14^{\circ} \mathrm{S}$, and $16^{\circ} \mathrm{S}$ within $2-19 \mathrm{~km}$ from the rise axis and from the top 75-100 m of ODP Site 1256 on the $15 \mathrm{Ma}$ Cocos plate. Monogenetic volcanoes form within $\sim 20 \mathrm{~km}$ from the rise axis or on the basement $<200 \mathrm{kyr}$, and are evenly distributed over the rise axis. Linearly aligned volcanoes and volcanic ridges occur farther from the rise axis than large lava fields and monogenetic volcanoes, and run subparallel to the direction of the Pacific plate motion. The Sojourn Ridge, the largest volcanic ridge, extends up to $440 \mathrm{~km}$ in length and is several hundred cubic kilometers in volume. Eruptive ages along a volcanic ridge and a volcano chain contradict the hot-spot origin of these volcanic features. Negative free-air and residual mantle Bouguer anomalies correlate well with the linearly aligned volcanoes and volcanic ridges, suggesting excess magma supply beneath the volcanic edifices. Seismic experiments show volcanic ridges have no keel below the Moho, indicating compensation of surface loading by plate flexure and underplating.

Whole rock compositions of off-ridge volcanoes have a much wider spectrum than the adjacent axial lavas, spanning from depleted NMORB through TMORB to isotopically fertile EMORB. Some off-ridge lavas could be produced by the fractional crystallization of the same parent magma as the adjacent axial lavas. However, most off-ridge lavas originate from different parent magmas than the neighboring axial lavas. Some TMORB magmas including the $14^{\circ} \mathrm{S}$ large lava field are the mixing product of the NMORB and EMORB magmas. Copious differentiated lavas of the large lava fields require a large magma chamber as a the site for crystallization differentiation and magma mixing. The lava geochemistry of off-ridge volcanoes strongly suggests the presence of a magma source that is independent of the axial magma plumbing system.

Seismic tomography and seafloor compliance measurements beneath the northern EPR indi-
\end{abstract}

$*$ 静岡大学理学部地球科学教室

** 産業技術総合研究所地質調査総合センター

*** 海洋研究開発機構地球内部変動研究センター

* Institute of Geosciences, Shizuoka University

** Geological Survey of Japan, National Institute of Advanced Industrial Science and Technology

*** Institute for Research on Earth Evolution, Japan Agency for Marine-Earth Science and Technology 
cate that the presence of melt across the rise axis is restricted in a narrow zone $\sim 4 \mathrm{~km}$ in width through the crust, but has a $10-14 \mathrm{~km}$ wide distribution in the uppermost mantle. Broad distribution, volume, and geochemistry of off-ridge monogenetic volcanoes and large lava fields strongly suggest that the off-ridge volcanoes originated from the Moho transition zone (MTZ). The MTZ is formed by a reaction between the uprising magma and the host mantle peridotite, leaving replacive dunite that experienced variable depletion and enrichment processes. Passive asthenospheric upwelling beneath the fast-spreading ridges produces a broad partial melt zone, through which magma ascends and accumulates beneath the off-ridge lithosphere. More depleted off-ridge magmas than axial magmas differentiate and mix with residual magmas in the MTZ, and react with variably enriched, impregnated dunite, resulting in variety of off-ridge lava compositions.

Small clusters of volcanoes and linear volcano chains are created by partial melting in asthenospheric return flows or local instability of the thermal boundary layer beneath the cooling lithosphere. Linear volcano chains will develop into long and robust volcanic ridges extending several hundred kilometers in length.

Key words : East Pacific Rise, off-ridge volcanism, large submarine lava field, submarine volcanic ridge, Moho transition zone

キーワード : 東太平洋海膨，オフリッジ火山活動，巨大海底溶岩原，海底火山脈，モホ遷移带

\section{I. はじめに}

中央海嶺系の火山・熱水活動や火成活動に関す る研究は，これまで火山活動や構造運動が活発な 拡大軸上の狭い火山帯に集中して行われてきた。 そのため, 中央海嶺系のマグマ組成に関する知見 や生成モデルも主として拡大軸近傍の限られた範 囲の観測に基づいている。一方，地球上で最も高 速で拡大している東太平洋海膨周辺の地震波速度 構造探査によると, 海洋地殼第 2 層は海膨軸か ら 1-4 km 離れたオフリッジで厚さを増し, 海膨 軸上のおよそ 2 倍になることが知られている (Harding et al., 1993; Kent et al., 1994; Hooft et al., 1996, 1997; Carbotte et al., 1997)。これ は，海膨軸上で噴出した溶岩が数 $\mathrm{km}$ 以上流下し てオフリッジにおいて第 2 層に付加するためと 考えられてきた（Hooft et al., 1996）。ところが, 東太平洋海澎から離れたところで噴出したと考え られる新しい溶岩原や火山が数多く存在すること が近年明らかとなってきた（図 1)（Batiza and Vanko, 1984; Macdonald et al., 1989; Perfit et al., 1994; White et al., 1998, 2002; Hilde and
Kisimoto, 2003; Kisimoto and Hilde, 2003)。著 者らは 2004 年夏に「よこすか」と「しんかい $6500 」 に よ る$ 東太平洋海膨南部の潜水調查 （YK04-07）を行い，南緯 14 度の海嶺軸西方 2$19 \mathrm{~km}$ において第四紀完新世の海底溶岩流とし ては世界最大規模の溶岩原を発見した（図 1, 図 2）（海野ほか, 2004; Geshi et al., 2007）。この巨 大溶岩原は面積 $346.3 \mathrm{~km}^{2}$, 体積 $25.4 \mathrm{~km}^{3}$ に達 し，それまでに知られていた海底溶岩流で最大規 模であった東太平洋海膨南緯 8 度の溶岩原 (図 3) (Macdonald et al., 1989; Hall and Sinton, 1996) の $15 \mathrm{~km}^{3}$ をはるかに凌ぐ。この噴出量はアイス ランドにおいて 2000 年に一度の頻度で起こる大 噴火によって生じる溶岩流の規模に匹敵し (Thordarson and Self, 1998), 地球全体の年平 均マグマ噴出量 4-5 $\mathrm{km}^{3}$ （Crisp, 1984）の数倍 に達する。したがって，これらのオフリッジ火山 は, オフリッジにおける海洋地殼第 2 層形成の 主体を担っている可能性がある。

これらの噴出物は枯渴した未分化 NMORB (Normal MORB : 一般的な中央海嶺玄武岩) か ら EMORB（Enriched MORB : 不適合元素など 
(A)

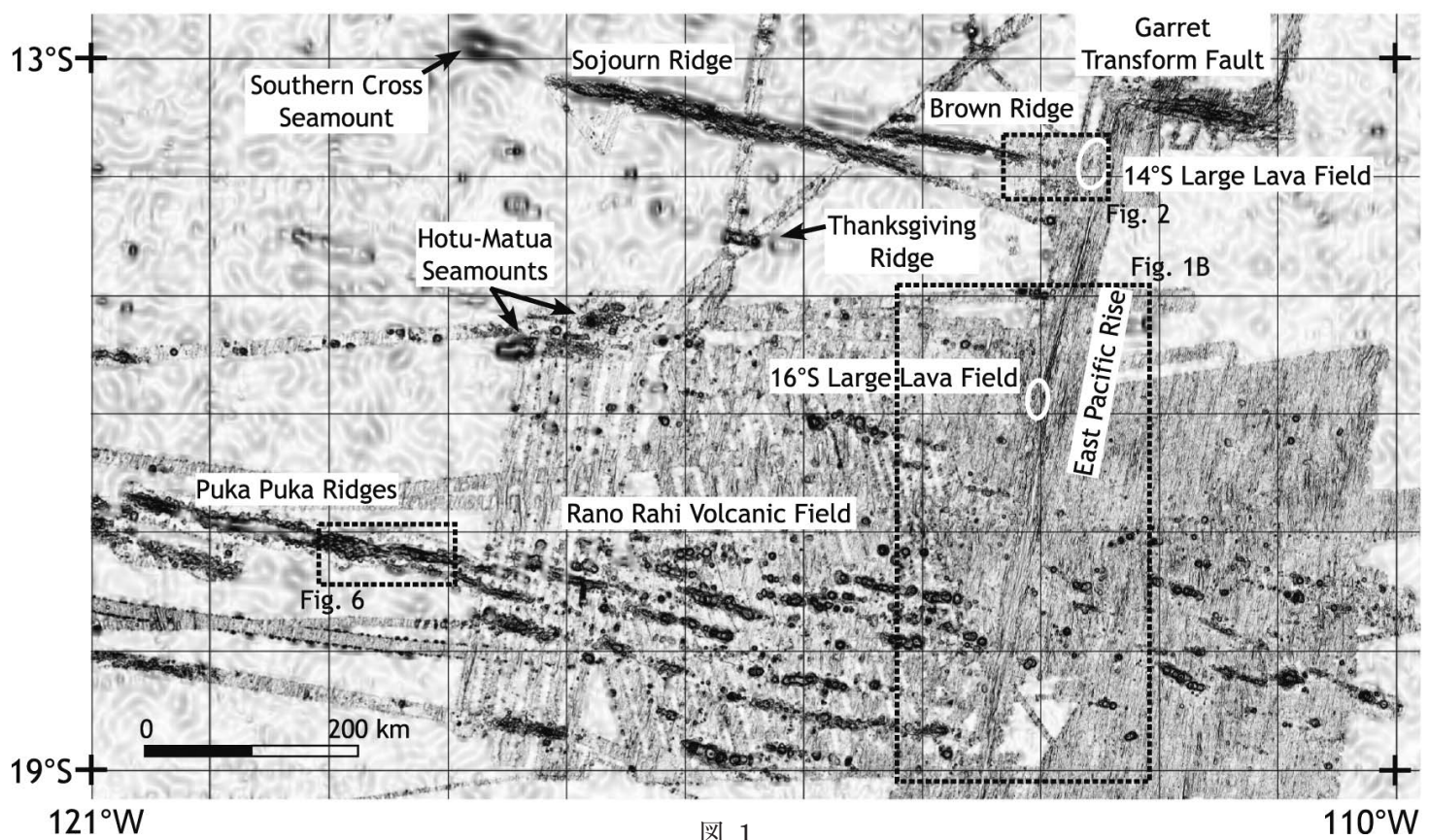

Fig. 1

に富んだ中央海嶺玄武岩）まで海膨軸上の NMORB よりも組成の変化に富み, 海膨軸下マ グマ溜り (Axial Magma Chamber, 以下 AMC と略す）とは独立のマグマ供給系の存在が示唆さ れる (Batiza et al., 1990; Hall and Sinton, 1996; Niu and Batiza, 1997; Reynolds and Langmuir, 2000; Geshi et al., 2007)。Spiegelman and Reynolds（1999）は拡大軸下で発生するマグマ 組成についてモデルシミュレーションを行い, ア セノスフェア上昇流の対流様式とマグマの上昇経 路の違いにより様々な組成が生じ得ることを示し た。プレート運動に誘引される受動的なアセノス フェア対流中では, 拡大軸直下よりもオフリッジ で上昇するマグマの方が不適合元素により枯渴し た組成となる。反対に積極的なマントル対流にお いてはアセノスフェア上昇流が拡大軸直下に収束 するために，拡大軸に比べてオフリッジの方が不 適合元素に富んだマグマ組成となる。高速拡大海 嶺下では受動的なアセノスフェア上昇流の発生が 期待される。もしそれが真実であるならば，東太
平洋海膨の拡大軸部溶岩よりもエンリッチしたオ フリッジ溶岩の存在は Spiegelman and Reynolds（1999）モデルでは説明困難である。一方， ある種の高速拡大海嶺であったとされるオマーン オフィオライトでは, マントルカンラン岩の変形 流動組織から直径数キロメートルのダイアピル状 のアセノスフェア上昇流が拡大軸に沿って 20-30 $\mathrm{km}$ 間隔で存在したと提唱されている (Jousselin et $a l ., 1998$ など)。東太平洋海澎ではダイアピル 状のマントル上昇流はいまだに見出されていな い。しかしながら，オマーンオフィオライトのカ ンラン岩が示すダイアピル状の流動組織から期待 される地震波速度の異方性は現在の観測精度では 検出が困難であり, 高速拡大海嶺下におけるマン トルダイアピルの存在が完全に否定されたわけで はない (Jousselin et al., 2003)。

1990 年代の初頭に東太平洋海膨の拡大軸下の 地殼構造について地震波トモグラフィーに基づい た新しいモデルが提唱された。拡大軸直下 1 $2 \mathrm{~km}$ に液が濃集したメルトレンズを持ち, 下部 
(B)

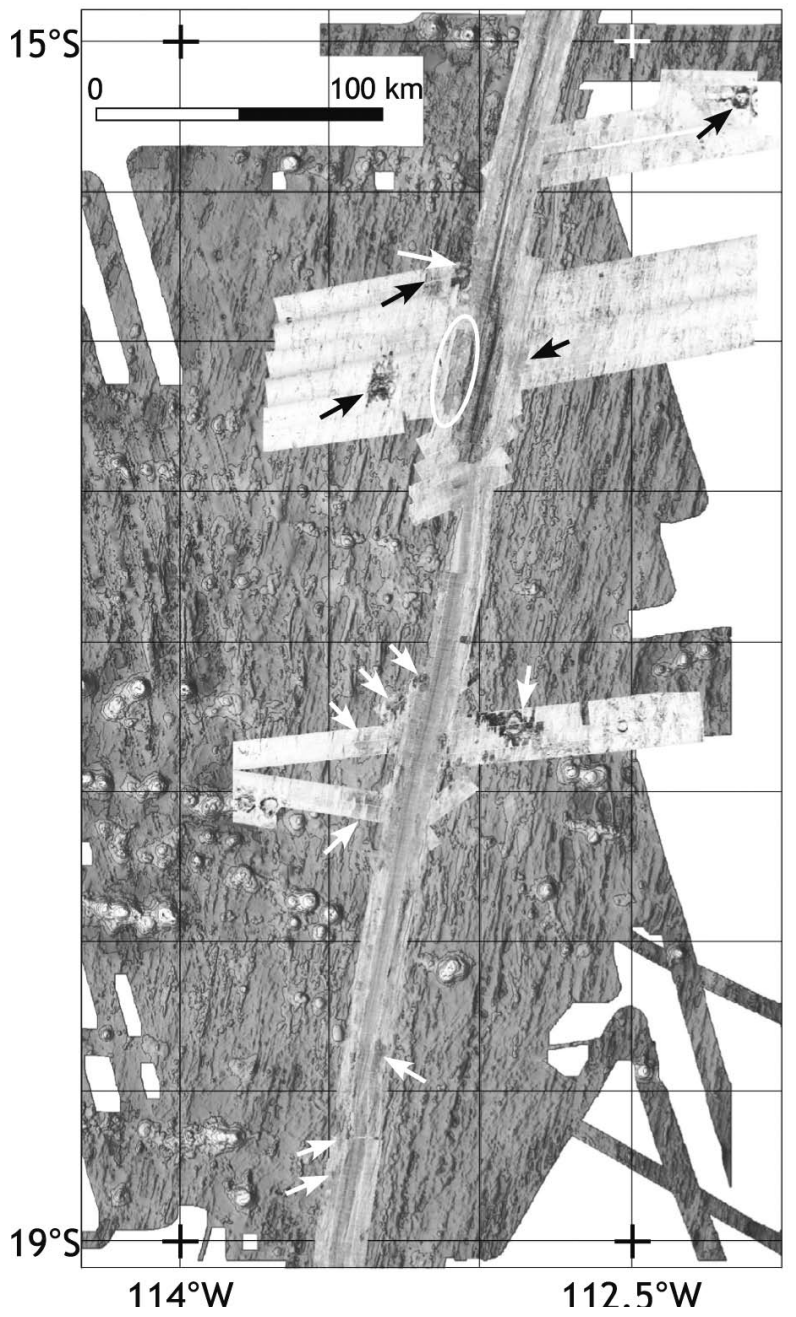

図 1 東太平洋海膨周辺の地形と主なオフリッ ジ火山の分布.（A）マルチビーム音響測深 および衛星重力データに基づく陰影地形図 (Smith and Sandwell, 1997). 水深データは Global Multi-Resolution Topography（GMRT) Synthsis $^{1)}$ および本研究による。白丸は 14 ${ }^{\circ} \mathrm{S}$ と $16^{\circ} \mathrm{S}$ 巨大溶岩原。黒破線で囲んだ四 角は図 $1 \mathrm{~B}$, 図 2 , 図 6 の範囲を示す。(B) 南緯 15-19 度のシービーム海底地形図と東 太平洋海膨に沿った $[\mathrm{TAMU}]^{2}$ サイドスキャ ン画像. 白丸は $16^{\circ} \mathrm{S}$ 巨大溶岩原。東太平 洋海膨の両側 $20 \mathrm{~km}$ 以内では拡大軸とほぼ 平行に火山体が配列する（15.7度付近の白 矢印など)。より外側ではプレート拡大方 向に火山が配列する。 $20 \mathrm{~km}$ 以上海膨軸か ら離れたオフリッジにも新しい溶岩流（サ イドスキャン画像で矢印が指す周囲よりも 暗色部）が見える.

Fig. 1 Off-ridge volcanoes around the southern East Pacific Rise (EPR). (A) Seafloor topography derived from multibeam and satellite predicted bathymetry (Smith and Sandwell, 1997). Data sources are Global Multi-Resolution Topography (GMRT) Synthesis $^{1)}$ and this study. White circles represent the locations of the $14^{\circ} \mathrm{S}$ and $16^{\circ} \mathrm{S}$ large lava fields. Broken solid squares indicate the areas shown in Figs. 1B, 2, and 6. (B) Bathymetry around the southern EPR $15^{\circ}-19^{\circ} \mathrm{S}$ and the $[\mathrm{TAMU}]^{2}$ sidescan image along the rise axis. Volcanoes within approximately $20 \mathrm{~km}$ from the EPR are arranged subparallel to the rise axis (white arrow at $15.7^{\circ} \mathrm{S}$ ), while those beyond the 40 $\mathrm{km}$ wide zone along the rise axis are aligned subparallel to the spreading direction of the Pacific and Cocos plates. Young lava flows are present more than $20 \mathrm{~km}$ off axis (dark areas shown by the $[\mathrm{TAMU}]^{2}$ image).
ほど結晶度が高い結晶マッシュ (crystal mush) 状のマグマ溜り像が広く受けいれられた(Toomey et al., 1990; Sinton and Detrick, 1992)。しかし, このマグマ溜り像はその後の研究の進展により変 更を余儀なくされつつある(Garmany, 1989; Dunn et al., 2000; Crawford and Webb, 2002)。 北緯 9 度では東太平洋海膨軸直下の $\mathrm{P}$ 波の低速 度異常領域の幅は狭く, 中部〜深部地殼にメルト はほとんどなく，地殼とマントルの境界部（モホ 遷移帯）に AMC の 1.4 倍ものマグマが存在する (Dunn et al., 2000)。また，海膨軸から 8-14 km
離れた下部地殼〜モホ遷移帯にメルトポケットの 存在が示されている (Crawford and Webb, 2002)。すなわち，オフリッジのモホ遷移帯に存 在するマグマが無数のオフリッジ火山の給源と なった可能性が考えられる。モホ遷移帯はマント ル中を上昇してきたマグマが母岩と最終的に化学 的平衡に達する反応帯である (Arai and Matsukage, 1996; Arai et al., 1997; 荒井・阿部 , 2003; Arai, 2005)。モホ遷移帯において, 不適合元素 に富んだ分化したマグマポケットの同化・混合や 生成時期の異なるマグマの混染を受けた母岩との 


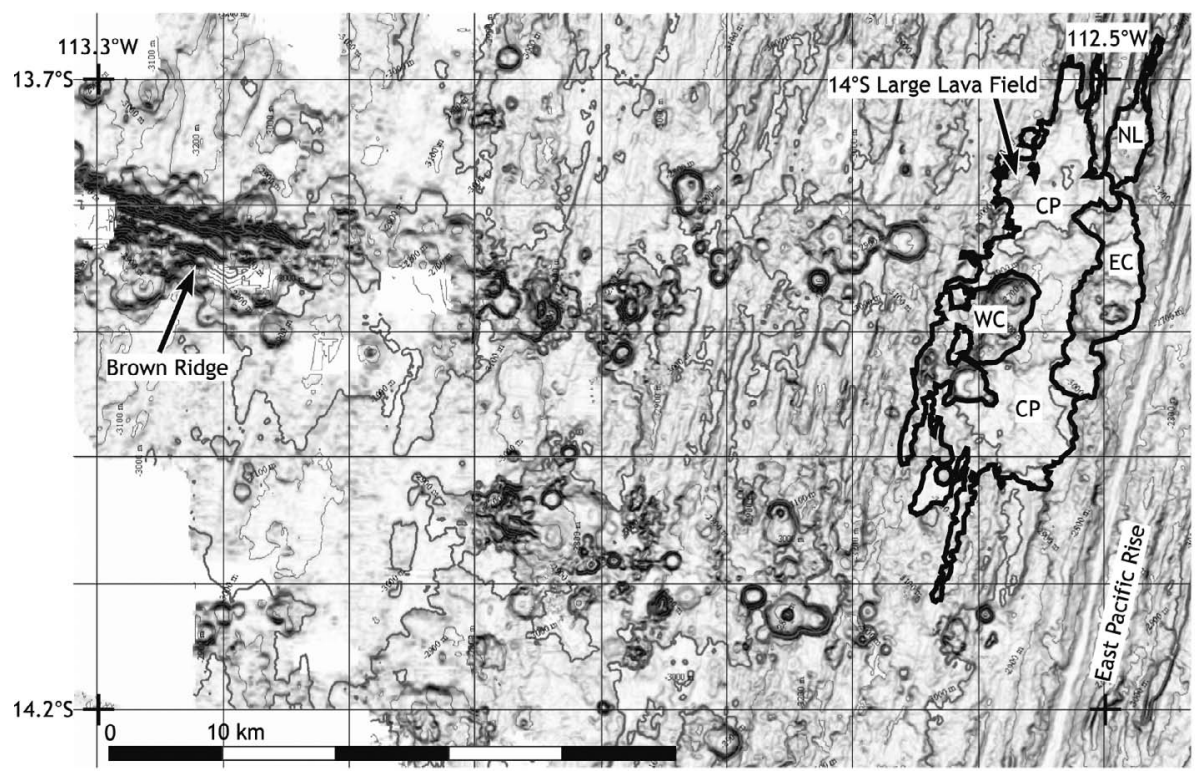

図 2 東太平洋海膨 $14^{\circ} \mathrm{S}$ 巨大溶岩原と Brown Ridge の陰影地形図 (位置は図 1 参照)。水深デー夕は本研究 による。巨大溶岩原の分布と各領域を黒線で囲んで示す。 EC：東海丘, CP：中央溶岩平原, WC：西 海丘群, NL：北部溶岩ローブ. 東太平洋海膨の西側には数多くの平頂円錐型火山がみられる。 $14^{\circ} \mathrm{S} 巨$ 大溶岩原から Brown Ridge にかけて左ずれに雁行状配列した火山群が分布する.同じ左ずれ雁行状配 列は Brown-Sojourn-Southern Cross Ridge 全体を通してみられる。西海丘群は海膨軸と平行に配列して いるのに対して，ょり西方に分布する火山群は西北西-東南東に配列する傾向がみられる.

Fig. 2 Shaded relief map of the $14^{\circ} \mathrm{S}$ large lava field and the Brown Ridge (Location of the mapped area is shown in Fig. 1). Bathymetric data are based on the present study. EC: East Cone, CP: Central Lava Plateau, WC: West Cones, NL: Northern Lobe. Note the abundant conical volcanoes at the western side of the EPR. Between the $14^{\circ} \mathrm{S}$ large lava field and the Brown Ridge, clusters of volcanoes are arranged in a left-stepping echelon. The left-stepping echelon arrangement of volcanic ridges can be seen along the entire BrownSojourn-Southern Cross Ridges. The West Cones are arranged subparallel to the rise axis, while the conical volcanoes in the west tend to form clusters stretching WNW-ESE.

反応によって，上昇したマグマが微量元素・同位 体組成を大きく変化させ，オフリッジマグマの多 様性を生じた可能性がある。

本論文では，巨大溶岩原をはじめとするオフ リッジ火山の産状とマグマの特徴について, これ までの研究成果を紹介する。モホ遷移帯の役割に ついては従来あまり考慮されてこなかったが, こ こでは特にオフリッジ火山との関係に注目し，モ ホ遷移帯の重要性を論じる。なお，本論文で用い た水深デー夕, 音響画像デー夕等の一部は海洋研 究開発機構の NIRAI-KANAI 研究航海(YK04-07) によって得られたものである。

\section{II. 東太平洋のオフリッジ海底火山群の 分布と産状}

太平洋の東部〜南部の海底にはオフリッジで噴 火・成長したと考えられる無数の海山や海山列が 存在する（図 1; Smith and Jordan, 1987, 1988; Alexander and Macdonald, 1996; Scheirer et al., 1996; White et al., 1998, 2002, 2006)。これ らは既知のホットスポットとは無関係な分布と形 成年代を示し，一般にプルーム由来の成分が認め られないことから, 中央海嶺系でもホットスポッ 卜起源でもない独立の単成火山や複成火山と考え られている (Sandwell et al., 1995; Scheirer et 


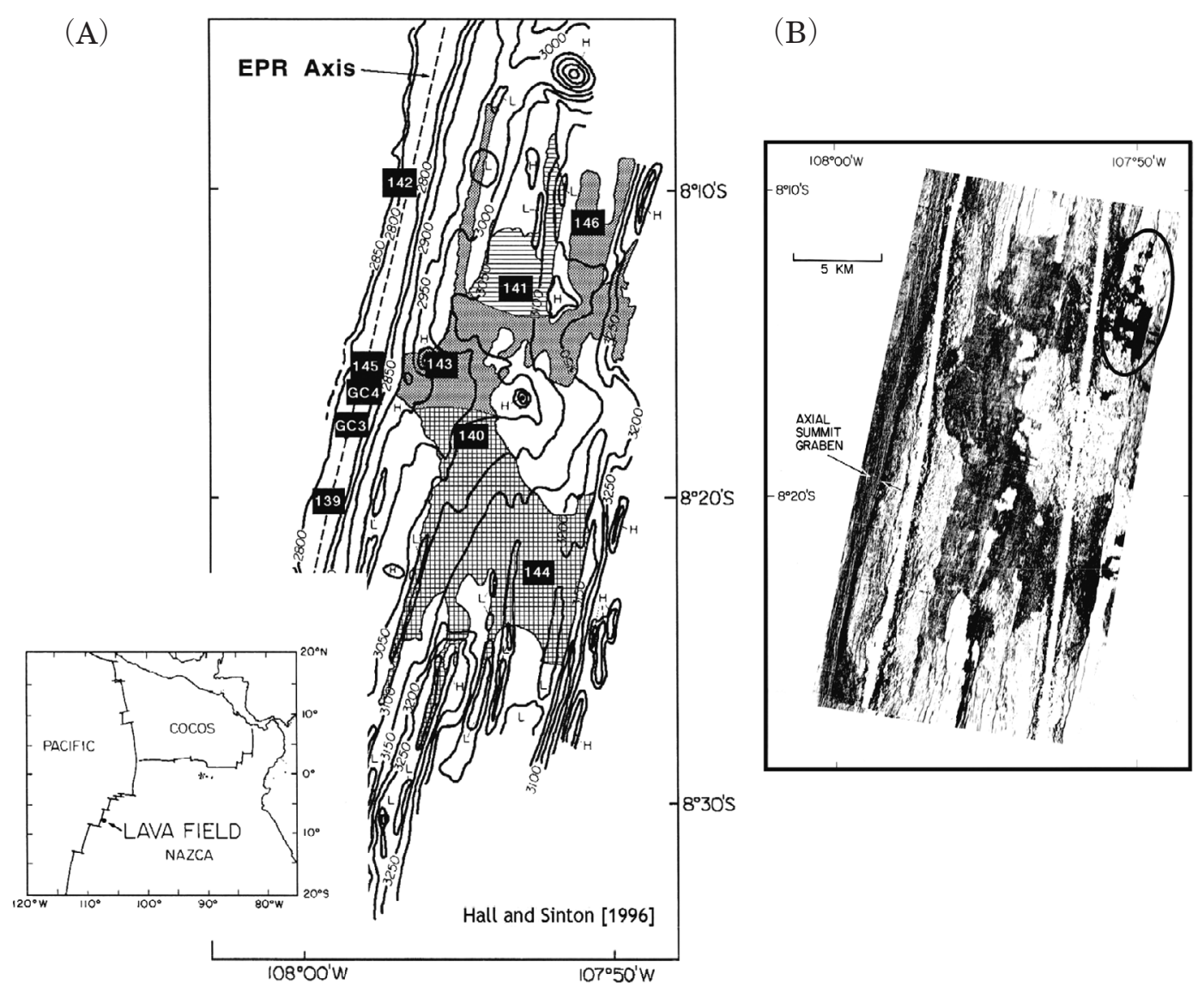

図 $3 \quad 8^{\circ} \mathrm{S}$ 巨大溶岩原の分布. (A) 全岩化学組成の特徵による分類 (Hall and Sinton, 1996). 網掛け模様：北 部溶岩原，横線：北部溶岩原北西部のローブ，格子模様：南部溶岩原，（B）音響反射画像（Macdonald et al., 1989). 丸で囲った北東端の最も黒い部分（反射強度が高い）が最新の溶岩ローブ.

Fig. $38^{\circ} \mathrm{S}$ large lava shield. (A) Subdivision of the flow field on the basis of the geochemistry of the lava (Hall and Sinton, 1996). Grey shading represents north lobe lava; crosshatch represents south lobe lavas; horizontal ruling represents the northwestern part of the north lobe, (B) Side-scan sonar image (Macdonald et al., 1989). The encircled darkest area in the northeast of the flow field is the latest flow lobe.

$a l ., 1996$; Hieronymus and Bercovici, 2000; Sohn and Sims, 2005; Forsyth et al., 2006; White et al., 2006)。

太平洋東部〜南部では, 100 万 $\mathrm{km}^{2}$ あたり高 さ $300 \mathrm{~m}$ 以上の火山は $1920 \pm 116$ 個, $500 \mathrm{~m}$ 以上の火山体は $959 \pm 30$ 個ある (Smith and Jordan, 1988)。特に東太平洋海膨南部の南緯 12-19 度の太平洋プレート上では 100 万 $\mathrm{km}^{2}$ あ たり 2333 個とオフリッジ火山が密集し，最長 $440 \mathrm{~km}$ に達する海底山脈が幾列も海膨軸とほぼ
直交して延びている（Scheirer et al., 1996; Forsyth et al., 2006; White et al., 2006)。

オフリッジ火山の分布が示す地域性には，年代 の古い地殼上で少なく，同じ年代であればより低 速で拡大する海嶺で形成された地殼上で多いとい う傾向が認められる。これは, 拡大速度の遅い地 殼の方が断層や亀裂の分布密度が高く, 弱線が多 いためと説明されている (Smith and Jordan, 1988)。オフリッジ火山の $73 \%$ は海嶺軸の近傍 で発生し, 残り $27 \%$ がさらにオフリッジで発生 
する。また，年代とともに火山体の個体数は増加 するが，高さ $1000 \mathrm{~m}$ 以上と $2000 \mathrm{~m}$ 以上の火山 のそれぞれ $78 \%$ と $93 \%$ がオフリッジで成長する (Smith and Jordan, 1988)。

東太平洋海膨南部周辺のオフリッジ火山の分布 密度は太平洋プレート上で高く, ナスカプレート 上で低い (Scheirer et al., 1996; Kisimoto and Hilde, 2003; Forsyth et al., 2006; White et al., 2006)。この非対称性は海底面深度にも表れてお り, 南緯 13 度付近の Garretトランスフォーム断 層よりも南で顕著である（Perrot et al., 1998）。 海底の沈降速度は緯度とプレート年代によって異 なるが，太平洋プレートが $350 \mathrm{~m} / \mathrm{Ma}^{1 / 2}$ を超えな いのに対し，ナスカプレートは最大 4 倍の沈降 速度を示す。この沈降速度の違いは単純な熱伝導 モデルでは説明できず，太平洋プレート下のアセ ノスフェアが高温であるためと考えられる (Perrot et al., 1998)。南緯 17 度で行われた電気伝導度 探査の結果，マントル上部にメルトが存在するの はナスカプレート下では海膨軸から $10 \mathrm{~km}$ 以内で あるのに対し，太平洋プレート下では西方 100 km に及ぶ（Baba et al., 2006)。したがって，南 部太平洋のオフリッジ火山の給源として上部マン トル中に広く分布するメルトが強く示唆される。

本論では, 東太平洋海膨のオフリッジ火山を分 布形態と産状から 3 種類に分けて解説する。(1) 個体数は少ないが大量の溶岩を流出した巨大溶岩 原（Large Lava Fields），(2）海膨軸の両側 15$20 \mathrm{~km}$ 以内で生じた独立単成火山（Independent Monogenetic Volcanoes)，(3) 前二者よりも才 フリッジで発生した火山列や尾根状の海底火山脈 である (Volcano Chains and Volcanic Ridges: Scheirer et al., 1996; Kisimoto and Hilde, 2003; Forsyth et al., 2006; White et al., 2006)。データ は限られるが，中央海嶺系に出現する溶岩流の規 模は拡大速度と逆相関する傾向があり，南部東太 平洋海膨軸部からは体積 $0.001-2 \mathrm{~km}^{3}$ の溶岩流 が知られている (Sinton et al., 2002)。地震波探 査で捉えられた東太平洋海膨軸直下のマグマ溜り (AMC) の体積は一般に 0.05-0.15 km $\mathrm{km}^{3}$ 程度であ ることが多く（Singh et al., 1998）, 最大規模で
もおよそ厚さ $100 \mathrm{~m} \times$ 幅 $1.5 \mathrm{~km} \times$ 長さ $12 \mathrm{~km}$ $<2 \mathrm{~km}^{3}$ である（Hooft et al., 1997）。そこで本 論では総体積 $2 \mathrm{~km}^{3}$ を超え, 音響画像の反射強 度等からほぼ同時期に定置したと考えられる溶岩 流の集合体を巨大溶岩原と呼ぶことにする。

\section{1）オフリッジ巨大溶岩原}

\section{(Large Lava Fields)}

南部東太平洋海膨周辺では南緯 8 度, 14 度, 16 度に巨大溶岩原が知られている（Macdonald et al., 1989; Kisimoto and Hilde, 2003)。また, ココスプレートの北緯 6 度 44 分にある深海掘削 サイト 1256 (Wilson et al., 2003）では $250 \mathrm{~m}$ の堆積物の下に厚さ $100 \mathrm{~m}$ を超えるオフリッジ 溶岩が見つかっている。南緯 16 度のものは海膨 軸の西 $70 \mathrm{~km}$ にあり，付近には火山群や火山列 がなく溶岩原のみが独立に存在する（図 1)。断層 に規制されて $33 \mathrm{~km} \times>4 \mathrm{~km}$ の範囲に広がり, 厚さを平均 $50 \mathrm{~m}$ とするとおよそ $7 \mathrm{~km}^{3}$ の巨大溶 岩原となる。潜水艇による調査や岩石試料のド レッジ等は行われておらず，詳細は不明である。

\section{1-1）8 $\mathbf{S}$ 巨大溶岩原}

$8^{\circ} \mathrm{S}$ 巨大溶岩原は 1987 年に SeaMARK II によ る音響画像マッピング中に Wilkes トランス フォーム断層の北 $114 \mathrm{~km}$ の東太平洋海膨東斜面 において発見された（図 3; Macdonald et al. 1989)。溶岩原は平均厚さ $70 \pm 20 \mathrm{~m}$ で南北 $35 \mathrm{~km} \times$ 東西 $13 \mathrm{~km}$ にわたって広がり, 面積 $220 \mathrm{~km}^{2}$, 体積 $15 \mathrm{~km}^{3}$ に達する。海膨軸の東麓 $2 \mathrm{~km}$, 水深 $2860 \mathrm{~m}$ 付近を海膨軸に平行に走る 尾根状の高まりがある。これは割れ目火口に沿っ て降下堆積したスパター（溶岩のしぶき）からな るスパターランパート（spatter rampert）と推 定されている。スパターランパート北端と北東方 にはそれぞれ比高 $40 \mathrm{~m}$ と $100 \mathrm{~m}$ ほどの海丘が あり, 雁行状に配列した割れ目火口の存在が示唆 される。溶岩原は割れ目火口の東 4-6 km にある 海丘を避けて南北 2 手に分かれ，末端は海澎軸 と平行な断層に規制されて地溝沿いに細く延びた 分布を示す (Macdonald et al., 1989)。北に延び た溶岩原の東端は音響画像から最も新しい溶岩 ローブと思われ，海膨軸の東 $12 \mathrm{~km}$ 付近に別の 
給源火口が示唆される（図 3)。北部溶岩原の北 東端はより未分化な無斑晶状溶岩であるのに対 し，噴火最末期に形成されたと思われる比高 $40 \mathrm{~m}$ の海丘は斜長石斑晶を持つやや分化した溶 岩からなる。また，北部溶岩原の北西部を占める 溶岩ローブは南部溶岩原とよく似た組成を有す る。このような溶岩分布から, 南部溶岩原と北部 溶岩原北西部のローブが定置した後に北部溶岩原 主部が流下し，分化した溶岩が火口丘を形成して 噴火が終息したと考えられる（Hall and Sinton, 1996)。

$8^{\circ} \mathrm{S}$ 巨大溶岩原は隣接する海膨軸上よりも高い 音響反射強度を示すことから，ごく最近の噴火に よって生じたらしい。1964，1965，1969 年の 3 回にわたって東太平洋海膨付辺でマグニチュー ド 4.5 の地震があり, $8^{\circ} \mathrm{S}$ 巨大溶岩原の西方 $3000 \mathrm{~km}$ の水深 2000-2500 m では 1970-1971 年に大量の ${ }^{3} \mathrm{He}$ を含む水塊（メガプルーム）が 観測された（Lupton and Craig, 1981）。Lupton and Macdonald（1988）は，推定されたメガプ ルーム中の ${ }^{3} \mathrm{He}$ 量が $15 \mathrm{~km}^{3}$ の立武岩質マグマに 含まれる ${ }^{3} \mathrm{He}$ ガスの総量に匹敵することから， 巨大溶岩の噴火によってメガプルームが発生した と考えた。 $8^{\circ} \mathrm{S}$ 巨大溶岩原においては深海カメラ や潜水艇などによる直接観察が行われたことはな く, 詳細な産状は不明である。数力所で新鮮な岩 石とガラス試料が得られており, 新しい噴出物で あることを裏付けている（Hall and Sinton, 1996)。

\section{1-2）14 $\mathbf{S}$ 巨大溶岩原}

$14{ }^{\circ} \mathrm{S}$ 巨大溶岩原は 1995 年に南緯 13-19 度で 行われた $[\mathrm{TAMU}]^{2}$ サイドスキャンソナーの曳 航調査でその一部がマッピングされ（岸本・ Hilde, 1998; Hilde and Kisimoto, 2003; Kisimoto and Hilde, 2003)，2004 年 7-8 月 の NIRAIKANAI 研究航海において支援母船「よこすか」 のシービーム・音響画像マッピングで初めて全貌 が明らかとされた（海野ほか, 2004; Geshi et al., 2007)。溶岩原は海膨軸の西 2-19 km に $49 \mathrm{~km}$ $\times 16 \mathrm{~km}$ にわたって広がり, 総面積 $420 \mathrm{~km}^{2}$, 体積 $25.7 \mathrm{~km}^{3}$ に達する。堆積速度と溶岩上の堆
積物の厚さからおよそ 2 万年前に噴火したと推 定されている（Geshi et al., 2007）。

溶岩原は地形的な特徵から 4 つの領域に区分 できる（図 2）。（1）溶岩原の東部を占める東海 丘とその南北に分布するテラス状の地形を示す ローブ状溶岩流からなる領域，（2）溶岩原の主 体をなす中央部のやや盛り上がった平滑な領域と その南北に続く低い平坦な下流域（中央溶岩平 原)，（3）溶岩原の西部に分布するやや古い平頂 海山列 (西海丘群)，（4）東海丘の北に続く最も 新しい北部溶岩ローブである。中央溶岩平原と北 部溶岩ローブの末端は狭い地溝に沿って延びてい る。地形的な特徵と分布, 音響画像の反射強度か ら, 西海丘群, 中央溶岩平原, 東海丘, 北部溶岩 ローブの順で形成されたと考えられる。またそれ ぞれの溶岩ローブ頂部の平坦面は東に約 1 度傾 いており，溶岩流定置後に溶岩流全体が傾動した と思われる。2004年の調査では「しんかい $6500 」 に よ る$ 観察が $14^{\circ} \mathrm{S}$ 巨大溶岩原で 4 潜航, 隣接する海膨軸で 2 潜航行われ, 各領域の海底 地形と噴出物の観察および岩石試料採取が実施さ れた。

東海丘と西海丘群はいずれも平坦な山頂の中心 に窪地があり， $5^{\circ}-18^{\circ}$ の斜面で囲まれた円盤型の 中心火山である（図 2)。斜面は最大傾斜方向に 流下した枕状溶岩で覆われている（しんかい第 828 潜航)。東海丘では山頂の平坦部にロベート シート溶岩 (lobate sheet flow)や陥没孔 (collapse pit）がみられ，枕状溶岩やロベートシート溶岩 からなる高さ 20-140 m の小溶岩丘が分布する。 東海丘から北東に続くテラスは北に向かって扇状 ないし半円形の溶岩ローブが段々畑のように重な り，それぞれの扇型ローブのフロントは枕状溶岩 がつくる $5^{\circ}-15^{\circ}$ の急斜面をなす（しんかい第 834 潜航)。

中央部の溶岩平原は，ほとんど平坦な表面地形 を示すシート溶岩からなり, 南部の低地では蛇行 する溶岩チャンネルが $[\mathrm{TAMU}]^{2}$ の音響画像で 認められる。溶岩チャンネル内は平滑なシート溶 岩で覆われ，ところどころに枕状溶岩を伴う小規 模なテュムラス（tumulus）が発達する（しんか 
い第 832 潜航）。またチャンネル中心部の陥没に 伴うとみられる幅数 $\mathrm{m}$ のクレバスがチャンネル の側端崖に平行に発達する。東西の海丘群に挟ま れた中央溶岩平原の部分は, 南北の平坦地よりも 50-100 m ほど盛り上がった高地になっており， 起伏に富んだ地形を示す。高地北部には半円状の 溶岩ローブが 3 段ほど積み重なったような地形 がみられる。高地の表面は平滑なロベートシート 溶岩とクラストが裮曲・破砕した破片で覆われた シート溶岩 (jumbled sheet flow) からなり，テュ ムラスが点在する（しんかい第 833 潜航）。西海 丘群北端の溶岩丘の東麓には比高 10-20 m の尾 根状の地形があり，その南方延長に高さ数 $10 \mathrm{~m}$ の小海丘が連なっている。地形から考えてこの尾 根が溶岩平原の大部分を噴出した火口列に沿って 形成されたスパターランパートの可能性がある。

NIRAI-KANAI 研究航海では「しんかい 6500」 にサブボトムプロファイラーを装備し, 堆積物の 厚さを計測した。堆積物は海膨軸からプレート拡 大方向に $8.5 \mathrm{~km}$ 離れた基盤岩（海膨軸で生じた 地殼）上で厚さ $2.0 \mathrm{~m}$ であった。基盤岩の形成年 代 $=$ 海膨軸からの移動距離 $8.5 \mathrm{~km} \div$ 西側拡大速 度 $7.5 \mathrm{~cm} / \mathrm{yr}=113,300$ 年から, 堆積速度 $1.8 \mathrm{~cm} /$ 千年と求められた。巨大溶岩原を覆う堆積物の厚 さは所により $70 \mathrm{~cm}$ に達することがあるものの, 大部分は約 $40 \mathrm{~cm}$ であった。これより，溶岩原 の定置年代はおよそ 22,700 年前と推定された。 したがって, 東海丘, 中央溶岩原, 西海丘群の推 定火口は噴火当時海膨軸からそれぞれ $1.9 \mathrm{~km}$,

$9 \mathrm{~km}, 11.5 \mathrm{~km}$ の位置にあったと考えられる。

溶岩流の大部分は斑晶量 $1 \mathrm{vol} \%$ 以下の無斑晶 状玄武岩溶岩で構成されており, 斜長石斑晶（< $5 \mathrm{vol} \%$ ）に富む玄武岩が東西の海丘に少量産す る。石基には $0.5 \mathrm{~mm}$ 以下の斜長石・カンラン石 微斑晶が比較的多い。これらの微斑晶はいずれも 板状あるいは針状で，しばしば骸晶状組織を示 す。溶岩の発泡度は低く, 枕状溶岩の中心部に少 量の気泡が認められるのみである。いずれも比較 的新鮮で，ガラス質部分の表面は割れ目にそって 深さ $1 \mathrm{~mm}$ 程度までパラゴナイト化が認められ る。マンガン酸化物の皮膜の厚さは $2 \mathrm{~mm}$ 以下
で，採取された場所による有意な差はみられない ことから, $14^{\circ} \mathrm{S}$ 溶岩原は比較的短時間で噴出・ 定置したと考えられ，溶岩形態の示す高噴出率と 矛盾しない。

\section{1-3）掘削サイト 1256 巨大溶岩原}

$8^{\circ} \mathrm{S}$ や $14^{\circ} \mathrm{S}$ のように新しい巨大溶岩原では詳 細な分布や溶岩流の表面構造を調べることができ るが，岩体内部の構造や組成変化等を解析するこ とは困難である。深海掘削サイト 1256 では厚さ $100 \mathrm{~m}$ を超えるオフリッジ溶岩を貫通して連続 コアを採取しており，巨大溶岩の内部構造を知る ことができる貴重な例である。掘削サイト 1256 は， 1500 万年前に $22 \mathrm{~cm} / \mathrm{yr}$ で超高速拡大してい た東太平洋海膨で形成されたココスプレート上の 地磁気縞異常 C5Br-C5Bn 境界に位置する（Wilson et al., 2003, 2006)。ここはトランスフォー 么断層や大きな重複拡大軸で分断されることなく 長さ $500 \mathrm{~km}$ 以上にわたって続く海嶺軸セグメン トの中央付近にあたる（Wilson, 1996）。第 206 次掘削航海で掘られた 4 つの掘削孔のうち, 北 と南に $30 \mathrm{~m}$ 離れた $1256 \mathrm{C}$ 孔と D 孔の基盤岩最 上部で同じ岩体と思われる厚い塊状溶岩を貫通し た。塊状溶岩は C 孔で $75 \mathrm{~m}, \mathrm{D}$ 孔で $100 \mathrm{~m}$ 以 上の厚さがあり, 溶岩上面の深度がほぼ同じであ ることから, 落差数 $10 \mathrm{~m}$ 以上の断層崖が発達す る 5-10 km オフリッジで地溝を埋積した溶岩池 と解釈された（Wilson et al., 2003）。岩石磁気の 伏角が溶岩池で急傾斜し，それより下位で緩傾斜 であることから，サイト 1256 の地殼の大部分が 形成された逆帯磁期から正帯磁期への転換期に溶 岩池が定置したと考えられる（Wilson et al., 2003)。サイト 1256 は基盤の表層 $100 \mathrm{~m}$ までの $\mathrm{P}$ 波速度が $4.8 \mathrm{~km} / \mathrm{s}$ を超える高速度領域の北部 に位置する（Teagle et al., 2006)。20 km × $12 \mathrm{~km}$ にわたって広がる高速度領域が厚さ $250 \mathrm{~m}$ の堆積物に隠されたオフリッジ溶岩であ るとすると, 平均厚さを $50 \mathrm{~m}$ としても体積は優 に $10 \mathrm{~km}^{3}$ を超える巨大溶岩原となる。

1256C 孔では上下の溶岩クラストを含むほぼ 連続した溶岩コアが回収された（コア回収率 91\%)。上部溶岩クラストは折りたたみ褶曲が進 
んで破砕しており，高速で流れたために強い剪断 を受けた溶岩じわに特徵的な構造を示す (Crispini et al., 2006)。底部溶岩クラスト最下部（>厚 さ $30 \mathrm{~cm})$ は約 80 度の急斜面を流下した溶結ス パターからなり，スパター急冷縁のさや状褶曲に 流動変形の様子をみることができる (Crispini et $a l ., 2006)$ 。さらにこの溶結部は上位の溶岩自身 の熱による接触自変成作用を被り，バリオリチッ クな石基斜長石が等粒状に再結晶している (Umino, 2007)。このように, 海膨軸から $5-10 \mathrm{~km}$ 離 れたオフリッジにおいて溶岩噴泉で始まった噴火 は，基盤の起伏を大量の溶岩で埋積して巨大溶岩 原を形成したと考えられる (Crispini et al. 2006)。

溶岩池は急冷した上下のクラストを除いて全体 が粗粒の立武岩〜ドレライトからなる。大きな斑 晶はなく，急冷部に微斑晶としてカンラン石と少 量の斜長石，オージャイトを有する。溶岩池の大 部分は粗粒な無斑晶状を呈する。石基は主に斜長 石とオージャイトからなり，鉄チタン鉱物と鉄に 富んだピジョン輝石を含む。間隙充填物としてマ イクログラフィック組織を示す石英 +アルバイト 集合物，アパタイト，骸晶状磁鉄鉱一イルメナイ 卜を有する。1256C 孔では, 上から 3 分の 1 ほ どに顕著な結晶粒径変化がみられ，上部クラスト から下位に向けて斜長石，オージャイトが粗粒化 し, 短軸/長軸比が増加する。下部 3 分の 2 近く は粒径, 短軸/長軸比ともにほとんど変化しない。 このような結晶粒径の層序変化は，ハワイの Makaopuhi 溶岩湖にもみられる（Cashman and Marsh, 1988)。

サイト 1256 のように，オフリッジ巨大溶岩原 は現在の東太平洋海膨近傍だけでなく, 数 100 万年以上も前から海洋地殼最上部の構成物として 存在しており, 厚い堆積物の下には多くの巨大溶 岩原が隠されている可能性がある。

\section{2）独立単成火山}

(Independent Monogenetic Volcanoes) 2-1）独立単成火山の分布と活動時期

オフリッジで噴火したと考えられる火山には, 小規模なシート溶岩流や，枕状溶岩からなる低い
尾根，ほぼ円形の水平断面を有する溶岩丘がある (Perfit et al., 1994; Fornari et al., 1998; Perfit and Chadwick, 1998; White et al., 1998; Reynolds and Langmuir, 2000)。小規模シート溶岩や 枕状溶岩の尾根は海膨軸から数 $\mathrm{km}$ の範囲の精査 で見つかっており，海膨軸に平行な割れ目火口か ら噴出したと考えられている (Fornari et al., 1998; Perfit and Chadwick, 1998)。溶岩丘の山 容は直径に対して低い比高を有するつぶれた円錐 型が基本で，山頂に火口ないしカルデラと思われ る凹地を伴ったり, 大型の火山では複数の山体が 合体していびつな形を呈することもある（White et al., 1998; Geshi et al., 2007)。体積は最大 $30 \mathrm{~km}^{3}$ に達するものもあるが，多くは $0.1 \mathrm{~km}^{3}$ 以下である。これらの溶岩丘が枕状溶岩で構成さ れているとすると, 形成に要する時間は数日〜数 10 年と推定され，体積，活動期間ともに陸上の 1 回の溶岩流噴火と変わらない (White et al., 1998; Pyle, 2000)。溶岩丘は周囲の海底から独 立した海山として地形的に容易に認識されるた め，その分布についてはよく調べられている。

独立単成火山の $73 \%$ は海嶺軸の近傍で発生し, 短期間で活動を終息するが，27\%はオフリッジ でも成長を続けて大きな山体を築く（Smith and Jordan, 1988)。比高 $50 \mathrm{~m}$ 以上の単独または小 規模な溶岩流を伴う独立単成火山についてみる と，海膨軸上に存在するものは皆無で，いずれも 海膨軸から $1 \mathrm{~km}$ 以上離れた場所にあり，特に重 複拡大軸の近傍に多い傾向がある（White et al., 1998)。独立単成火山は，南部東太平洋海澎では 東西両側に対称的な分布を見せるが，後述する火 山列や火山脈の大多数は西側に発達する。オフ リッジ火山の分布は噴火のしやすさを左右する基 盤の構造的弱線や地殼の厚さなどと関係すると考 えられるので (Scheirer et al., 1996; White et al., 1998; Hieronymus and Bercovici, 2000; Sohn and Sims, 2005), 単純に海膨軸からの距 離よりも，基盤年代との関係をみる必要がある (図 4)。海膨軸から 20 万年前までは $1000 \mathrm{~km}^{2}$ あたりの火山数が単調に増加するが，それよりも 古い基盤上では火山数は 4-13 個の範囲内で増減 
(A)

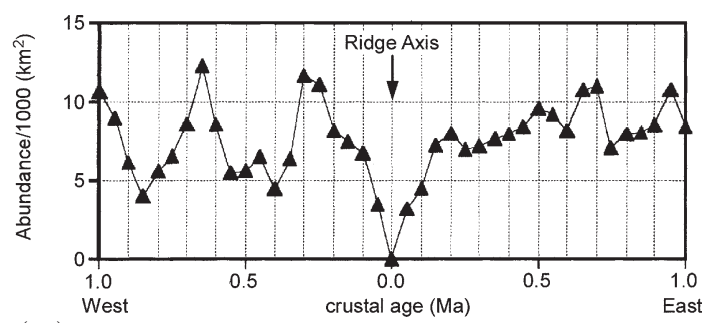

(B)

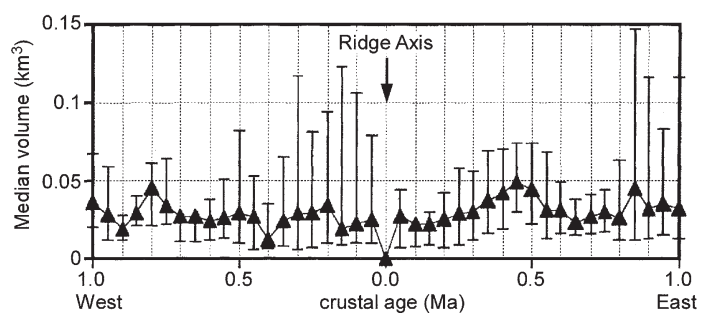

図 4 東太平洋海膨南緯 15-20 度周辺の $1000 \mathrm{~km}^{2}$ あた りの独立単成火山の個数 (A) と体積の中央値 $(\mathrm{B})$ (White et al., 1998).どちらも基盤年代で 5 万年 ずつ重複するょうに 10 万年ごとに区切っている. 体積の縦の棒は，火山体の 25-75\%が入る範囲を 示す.

Fig. 4 Abundance (A) and median volume (B) of isolated volcanoes off the southern EPR $15^{\circ}-20$ ${ }^{\circ} \mathrm{S}$ plotted against basement ages (White et al., 1998). Histogram bins are $0.1 \mathrm{Myr}$ wide and overlap by $0.05 \mathrm{Myr}$. Vertical bars show the range from the 25th to 75 th percentiles of edifice volumes, illustrating both the wide scatter and the skewness in the volume distribution of volcanoes.

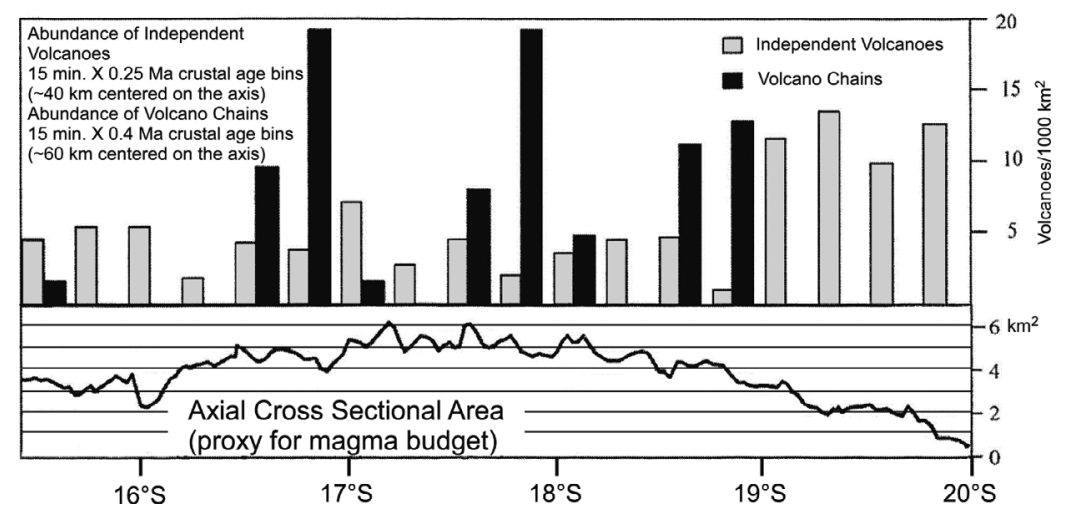

図 5 東太平洋海膨南緯 15.5-20 度のオフリッジ火山の数密度 (上図) と海膨軸に沿った断面積の変化 (下図； Scheirer and Macdonald, 1993)。海膨軸の両側 $20 \mathrm{~km}$ (独立単成火山）と $30 \mathrm{~km}$ (火山列)，軸方向に 15 分ごとに区切った矩形内の $1000 \mathrm{~km}^{2}$ あたりの火山数を示す。火山列は海膨軸断面積 $4 \mathrm{~km}^{2}$ 以上の所に 出現し, 独立単成火山が多い南緯 19-20度には火山列が存在しない.

Fig. 5 (Top) Total number of volcanoes in quarter-degree latitude bins, $40 \mathrm{~km}$ wide, and centered on the axis. Independent volcanoes abundances are normalized for the area covered by seamount chains in each bin. (Bottom) Cross-sectional area of the rise axis from Scheirer and Macdonald (1993). Volcano chains are found only where the cross-sectional area $\geq 4 \mathrm{~km}^{2}$, but independent volcanoes are found along the entire rise segment and increase in number from $19^{\circ}$ to $20^{\circ} \mathrm{S}$, where chain volcanoes are absent.

を繰り返している。また，火山体の体積の中央値 は, 10 万年前以降変化しない。同様の現象は, 大西洋中央海嶺 (Smith and Cann, 1992) や東 太平洋海澎北部 (Alexander and Macdonald, 1996）でも知られている。すなわち，独立単成 火山は 20 万年前より若い基盤上で発生し，10 万
年以上かけて成長するものはないと考えられる (White et al., 1998)。独立単成火山の数密度は 海膨軸が幅広く盛り上がった南緯 17 度や巨大溶 岩原がある南緯 14 度で低く，海膨軸の幅が狭い 南緯 15 度，19-20 度で高い（図 5）。一方，火山 列の数密度は南緯 17 度で大きく, 独立単成火山 
とは相補的な関係にある（White et al., 1998）。 $1000 \mathrm{~km}^{2}$ あたりの独立単成火山の総体積は数密 度とおおむね逆相関し， $17^{\circ} \mathrm{S}$ で大きく南緯 15 度 と 19-20 度では小さい（White et al., 1998）。

\section{2-2） $9^{\circ}-12{ }^{\circ} \mathrm{N}$ オフリッジ溶岩の産状}

東太平洋海膨北部では北緯 9-12 度にかけて海 膨軸を挟んだ両側数 $\mathrm{km}$ の範囲について, 潜水艇 や深海カメラ, 高解像度音響画像探査などによる 精査に加え，詳細な地震波構造探査が行われてい る (Toomey et al., 1990; Reynolds et al., 1992; Perfit et al., 1994; Dunn and Toomey, 1997; Fornari et al., 1998; Perfit and Chadwick, 1998; Crawford et al., 1999; Dunn et al., 2000; Reynolds and Langmuir, 2000; Crawford and Webb, 2002；Sims et al., 2003 など)。北緯 9 度 30 分10 度 00 分付近は海膨軸が盛り上がり，マグマ供 給率が高いと予想される (Macdonald and Fox, 1988; Scheirer and Macdonald, 1993)。北緯 9 度 31 分では海澎軸を含む南北 $4 \mathrm{~km} \times$ 東西 $8 \mathrm{~km}$ の範囲に，拡大速度から予想される基盤年代より も 2-7 万年も若い ${ }^{238} \mathrm{U}-{ }^{230} \mathrm{Th}$ および ${ }^{235} \mathrm{U}-{ }^{231} \mathrm{~Pa}$ 年代を示す溶岩が分布する (Goldstein et al., 1994）。これらの新しいオフリッジ溶岩は, 海膨 軸から 2-4 km 離れた割れ目火口から噴出した枕 状溶岩の尾根を形成している（Perfit and Chadwick, 1998)。

北緯 9 度 48 分-52 分では幅 2-5 km の海膨軸 はシート溶岩で覆われ，幅 $100 \mathrm{~m}$ 以下の浅い中 軸谷 Axial summit trough を持つ。ロベートシー 卜溶岩で覆われた中軸谷底には溶岩チャンネルが みられ，中軸谷に沿って $5 \mathrm{~km}$ も続いたり，中軸 谷から外へ海膨斜面を $1 \mathrm{~km}$ ほど流下している (Sims et al., 2003)。中軸谷の外側 2-4 km では 変位 10-20 m ほどの断層が発達し，オフリッジ の割れ目噴火によって生じた枕状溶岩の尾根や小 溶岩丘が断層崖を覆ったり，断層によって変位さ せられている。

東太平洋海膨の北緯 12 度 00 分-20 分付近の 海膨軸を挟む東西 $16 \mathrm{~km} \times$ 南北 $30 \mathrm{~km}$ の範囲で は，オフリッジ火山が海底面のおよそ $20 \%$ を占 め, 北緯 9 度と同様に枕状溶岩の小尾根や，断
層や亀裂を覆う新しい溶岩流，シート溶岩を伴う 高さ $100 \mathrm{~m}$ ほどの平頂溶岩丘を形成している (Reynolds and Langmuir, 2000)。

3) 火山列と火山脈

(Volcano Chains and Volcanic Ridges)

\section{3-1）分布，産状と成長過程}

南部東太平洋には平頂円錐型火山や溶岩流が線 状に配列して火山列をなしたり，あるいは狭い地 帯に火山体が密生した火山群が数多く分布する (図 1, 図 2)。さらに隣接する火山体が密接して 尾根状に積み重なり，巨大な海底山脈となったも のもある（図 1)。これらの海底火山脈や火山列 はプレート拡大方向とほぼ平行に延び，延長 25$440 \mathrm{~km}$ に及ぶ。大部分は太平洋プレート上にあ るが，Easter Seamount Chainのようにナスカ プレート上に存在するものもある（Sandwell et al., 1995; Scheirer et al., 1996; Rappaport et al., 1997; Forsyth et al., 2006; White et al., 2006)。 太平洋プレート上の火山列や火山群の西方延長上 には火山脈があることが多い。東太平洋海膨付近 では火山列は特に南緯 17 度，18 度，19 度に偏 在し, 海膨軸から 5-50 km 離れた太平洋プレー 卜上には数条の火山列からなる Rano Rahi 火山 群が広がっている（図 1)。Rano Rahi 火山群は 西方に向けて分布域を狭め, Puka Puka Ridge へ収束していく（図6）。Puka Puka Ridge は $1500 \mathrm{~km}$ にわたって雁行状に延びる火山脈から なり，西端はフレンチポリネシアの Tuamotu 諸 島の近辺にまで達する。 $14^{\circ} \mathrm{S}$ 巨大溶岩原から始 まる火山列は海膨軸の $70 \mathrm{~km}$ 西で Brown Ridge に移化し,さらに隣接して雁行する Sojourn Ridge, Southern Cross Seamount へ続く（図 1, 図 2)。Sojourn Ridge は火山脈中最大の規模を 有し, 延長 $440 \mathrm{~km}$, 周囲の海底からの高さ $3500 \mathrm{~m}$, 頂部の水深 $200 \mathrm{~m}$ に達する。雁行する Southern Cross Ridge，Brown Ridge とともに総 延長 $550 \mathrm{~km}$, 総体積 $700 \mathrm{~km}^{3}$ の巨大火山脈群を 形成する。また，南緯 14 度 30 分には延長 $146 \mathrm{~km}$ の Thanksgiving Ridge, 南緯 15 度-15 度 30 分 には Hotu Matua 火山群がある。後者は $450 \mathrm{~km}$ $\times 65 \mathrm{~km}$ にわたって新しい溶岩流を伴う数列の 


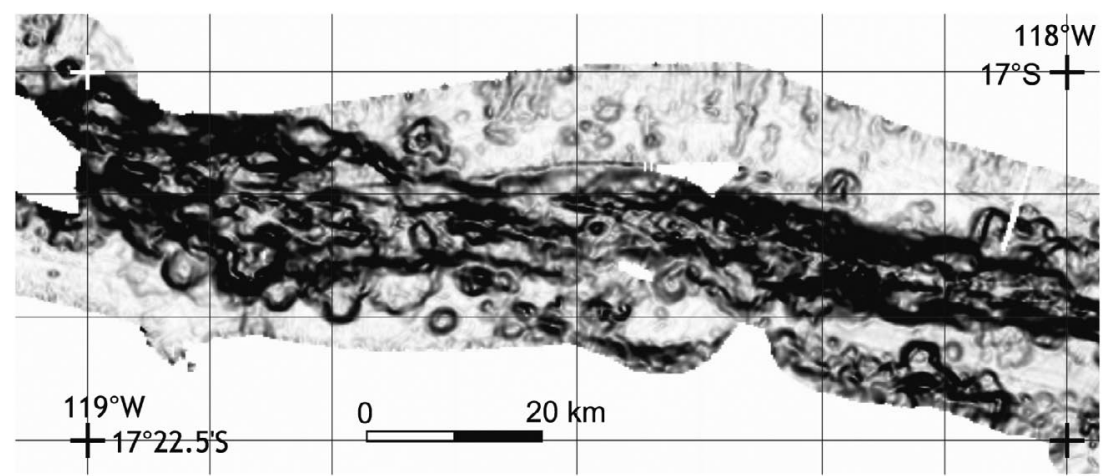

図 6 Puka Puka Ridge の拡大地形(位置は図 1 参照)。平頂円錐型火山が積み重なって尾根状の火山脈をつくる. グリッドデータの出所は図 1 と同じ.

Fig. 6 Topography of Puka Puka Ridge (Location of the mapped area is shown in Fig. 1). The volcanic ridge consists of superposed flat-topped conical volcanoes. Source of the bathymetric grid data is the same as Fig. 1 .

火山列と火山脈からなる (Forsyth et al., 2006)。 火山脈は独立単成火山と同様の小規模な平頂火 山体が積み重なってできており，小規模な噴火が 狭い地帯に集中して繰り返し発生した，一種の単 成火山群である（図 6)。火山列や火山脈を構成 する個々の火山体のほとんどは直径 $4 \mathrm{~km}$ 以下, 比高 $300 \mathrm{~m}$ に満たない。同様の火山脈は大西洋 中央海嶺やレイキャネス海嶺の中軸谷に普遍的に 見出されるが，これらはいずれも海嶺軸と平行に 配列する点で異なる（Smith and Cann, 1992; Magde and Smith, 1995; Smith et al., 1995)。

$14^{\circ} \mathrm{S}$ 巨大溶岩原の西から Brown Ridge へ続く 火山列では，西に向かって単位基盤年代あたりの 構成火山数，体積ともに単調に増加し，火山脈に 漸移する（White et al., 2006）。Brown Ridge や Sojourn Ridge では火山脈基部の幅は $10 \mathrm{~km}$ ほ どであるが，活動初期に形成されたと思われる小 火山体の分布はさらに外側まで広がっている。こ れらのことから，まず広い範囲に分散した小火山 体群が発生し，やがて噴火位置が次第に一つの線 上に収束していって火山列となり，最終的に幅 10-15 km の火山脈を形成したと考えられる (Lynch, 1999; Forsyth et al., 2006)。このよう な火山脈の形成過程は，火山体の荷重による線状 配列の形成モデルを支持する（Hieronymus and Bercovici, 2000)。

\section{3-2）火山列・火山脈の成因}

東太平洋海膨南部では相対的なプレート拡大方 向とホットスポットに対する絶対運動方向がほほ 一致しており（Scheirer et al., 1998），火山列や 火山脈の配列もこれらの方向に平行である。 Hotu Matua 火山群では 0.16-6.1 Ma の Ar-Ar 年代が得られているが，同じ火山列上の地理的位 置と年代の間に系統的な関係は存在しない（Forsyth et al., 2006)。Gravity Lineations Intraplate Melting Petrology and Seismic Expedition (GLIMPSE 計画) で 2001 年に行われた地震探 査で Matuaのすぐ北で微小地震が観測されてい ることから (Llenos et al., 2003), Matuaは現 在も活動中の火山群と考えられる。Puka Puka Ridge や Sojourn Ridge では，活動中心が西から 東へと移動しているが, 活動中心の移動速度はプ レート運動よりも速い上，同じ火山脈の複数個所 で同時期に活動している（Sandwell et al., 1995; Forsyth et al., 2006)。したがって，これらの火 山列・火山脈の成因はホットスポットでは説明で きない。

火山列や火山脈に沿って負のマントルブーゲー 異常が観測されており，厚い地殼または余剩のマ グマの存在を示唆する (Sandwell et al., 1995; Harmon et al., 2006)。Sojourn Ridge を横切っ て西経 115 度付近を南北に走る $450 \mathrm{~km}$ の測線 
に沿って行われた地震波探査によると，周辺の海 洋地殼の厚さは平均 $6.2 \mathrm{~km}$ でモホ面深度はほと んど変化がなく, Sojourn Ridge が $2 \mathrm{~km}$ ほど上 に突き出た分だけ地殼が $8.2 \mathrm{~km}$ と厚くなってい る（Holmes et al., 2007）。したがって，Sojourn Ridge は地殼の強度によって支えられている。火 山脈や火山列が集中する南緯 14 度と 17 度付近 は海膨軸が幅広く盛り上がり, 南部東太平洋海膨 中で最大の断面積を有することから（Scheirer and Macdonald, 1993)，海膨軸へのマグマ供給 率が高いと考えられているが，このことが巨大溶 岩原や火山脈の形成に関係する可能性がある。

\section{III. オフリッジマグマの起源}

\section{1）オフリッジマグマ組成の特徵}

東太平洋海膨周辺のオフリッジ火山を形成する マグマは多様で，一般に海膨軸溶岩よりも全岩化 学組成の変化に富んでいる。と同時に，近傍の軸 部マグマと共通の性質を有することも多く，成因 的な関係を示唆する。以下に，個々のオフリッジ 火山マグマの特徵について述べる。

\section{1-1）巨大溶岩原}

\section{1-1.1） $8^{\circ} \mathrm{S}$ 巨大溶岩原}

$8^{\circ} \mathrm{S}$ 巨大溶岩原のガラス組成は $\mathrm{MgO}$ 6.3-8.2 wt $\%, \mathrm{~K}_{2} \mathrm{O} / \mathrm{TiO}_{2}$ 比 0.04-0.10 の NMORB (Normal MORB : 一般的な中央海嶺玄武岩）で，北部溶 岩原北西部のローブを除いて主要元素組成は隣接 する海膨軸溶岩の組成範囲内にある。最も分化し た北部溶岩原北西部ローブは，南部溶岩原ととも に高い $\mathrm{Sr}$ 含有量を示す。 $\mathrm{Nb} / \mathrm{Y}$ 比と $\mathrm{K} / \mathrm{Ti}$ 比は北 部溶岩原北西部ローブと南部溶岩原で最も高く, 隣接する海膨軸溶岩, 北に流れた溶岩の順で低く なり, 後者ほどマントルの部分溶融程度が高かっ たとされている（図 7; Hall and Sinton, 1996）。

\section{1-1.2） $14 \stackrel{\circ}{\mathrm{S}}$ 巨大溶岩原}

$14^{\circ} \mathrm{S}$ 巨大溶岩原は全体として不適合元素にそ しく組成幅が大きい（MgO 6.6-8.9, Mg\# 4864）（Geshi et al., 2007）。北部溶岩ローブと西 海丘，また東海丘の大部分は NMORB であるが, 山頂部の溶岩丘は軽希土類/重希土類元素濃度比 が他よりも高い EMORB (Enriched MORB : 不
適合元素などに富んだ中央海嶺玄武岩）からなる （図 8）。溶岩原の主体をなす中央溶岩平原は最も 分化しており $(\mathrm{MgO}$ 6.5-7.8 wt\%)， $\mathrm{K}, \mathrm{Ti}$ ，希 土類元素濃度がやや高く, TMORB（NMORB と EMORB の中間的な化学組成を有する中央海 嶺玄武岩）の特徵を示す。 ${ }^{3} \mathrm{He} /{ }^{4} \mathrm{He}(\mathrm{R} / \mathrm{RA})$ 比 は 8.13-8.98, ${ }^{87} \mathrm{Sr} /{ }^{86} \mathrm{Sr}$ 比は東海丘の EMORB (0.70269) を除いて 0.70241-0.70259 といずれも NMORB の範囲内にあり，プルーム的な成分は認 められない。TMORBの組成変化は NMORB 85\%と EMORB 15\%の混合によって生じたマグ マから斜長石とカンラン石を結晶分別することで 説明可能である（Geshi et al., 2007）。

\section{1-1.3）掘削サイト 1256 巨大溶岩原}

巨大溶岩原の一部を掘削した溶岩池は，サイト 1256 の溶岩，岩脈中で最も分化しており，低い $\mathrm{Mg \#}(69.7 \pm 3.6)$, 高い $\mathrm{FeO}(13.4 \pm 1.0 \mathrm{wt} \%)$, $\mathrm{TiO}_{2}(1.9 \pm 0.3 \mathrm{wt} \%), \mathrm{Nb}(4.33 \pm 1.18 \mathrm{ppm})$, $\mathrm{P}_{2} \mathrm{O}_{5}(0.16 \pm 0.03 \mathrm{wt} \%)$ で特徵付けられる（図 $9)$ 。特に $1256 \mathrm{C}$ 孔では結晶粒径が極大となる層 準の直下に飛び抜けて高い $\mathrm{K}_{2} \mathrm{O}(0.54-0.75 \mathrm{wt} \%)$ を含有する層準が厚さ $10 \mathrm{~m}$ にわたって出現する。 これは溶岩池の定置・冷却・結晶分化過程によっ て形成された構造と考えられるが，詳細な研究は これからである。溶岩池よりも下位の溶岩には $\mathrm{Nb} / \mathrm{Zr}$ 比が高い少数グループと大多数を占める低 $\mathrm{Nb} / \mathrm{Zr}$ 比グループがあり，溶岩池は中間的な $\mathrm{Nb} /$ Zr 比を示す (Wilson et al., 2003)。したがって, オフリッジ溶岩池は海膨軸近傍のマグマとは異な る親マグマから分化したと考えられる（Teagle et al., 2006)。

\section{1-2）独立単成火山 $\left(9^{\circ}-\mathbf{1 2}^{\circ} \mathrm{N}\right.$ オフリッジ溶岩 $)$}

北緯 9 度 31 分周辺のオフリッジ溶岩の全岩化 学組成は主として海膨軸溶岩と同様の NMORB 組成を有するが，組成の変化幅が大きく，北緯 9 度 03 分から Clipperton トランスフォーム断層 までの間に分布するすべての海膨軸溶岩の組成範 囲にわたる（図 10; Perfit et al., 1994）。また，海 膨軸の東 2-4 km には $\mathrm{K}_{2} \mathrm{O} / \mathrm{TiO}_{2}$ 比 $0.15-0.22$ の EMORB 溶岩が分布する。

北緯 9 度 50 分のオフリッジ溶岩はすべて 
(A)

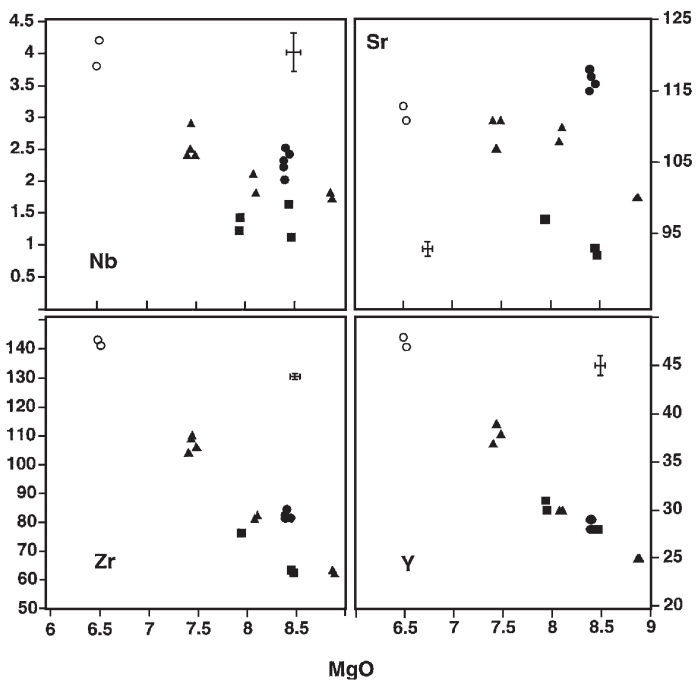

(B)
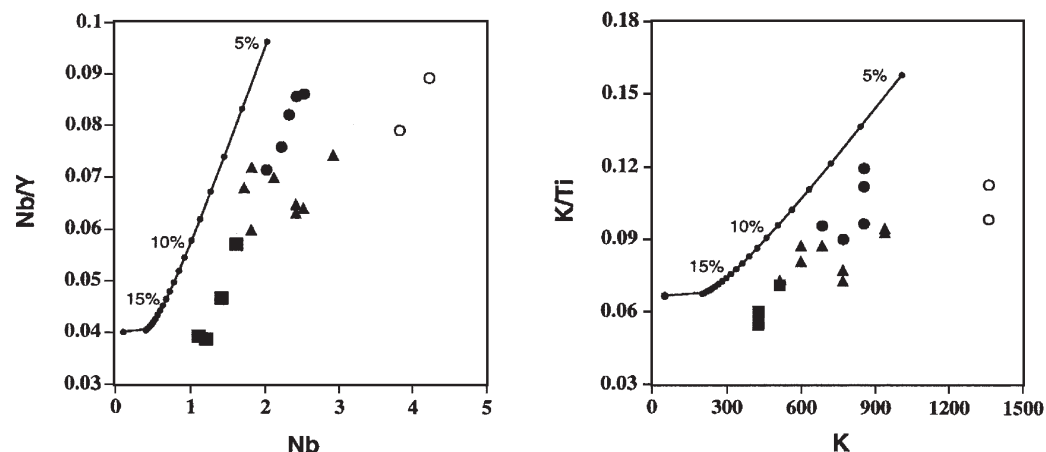

図 $78^{\circ} \mathrm{S}$ 巨大溶岩原の全岩化学組成 (Hall and Sinton, 1996). 黒三角：海膨軸部溶岩, 黒丸：南部溶岩原, 白丸：北部溶岩原北西部のローブ, 黒四角：北部溶岩原. (A) $\mathrm{MgO}$ に対する $\mathrm{Nb}, \mathrm{Sr}, \mathrm{Zr}, \mathrm{Y}$ の変化図. $\mathrm{Sr}-\mathrm{MgO}$ から海膨軸部，北部，南部溶岩が同じ親マグマからの結晶分化では導けないことがわかる. （B）マントルカンラン岩が最大分別溶融（Shaw, 1970）したときの部分溶融程度とマグマ中の $\mathrm{Nb} / \mathrm{Y}$ 比 と $\mathrm{K} / \mathrm{Ti}$ 比の変化. ソースマントルのモード組成と溶融割合は Johnson et al. (1990) による.

Fig. 7 Lava geochemistry of the $8^{\circ} \mathrm{S}$ large lava field (Hall and Sinton, 1996). (A) Solid triangle: axial lava, solid circle: Southern lobe, open circle: Northwestern lobe, solid square: Northern lobe. The Sr-MgO variation indicates that the axial lava, northern and southern lobes cannot be produced by the crystallization differentiation of a common parent magma. (B) $\mathrm{Nb} / \mathrm{Y}$ and $\mathrm{K} / \mathrm{Ti}$ ratios and model fractional crystallization trends for the axial and the large lava field based on Shaw (1970), and using the model parameters of Johnson et al. (1990).

$\mathrm{K}_{2} \mathrm{O} / \mathrm{TiO}_{2}<0.10, \mathrm{Mg} \#$ 50-64 の NMORB で, やや分化しているものの，未分化マントルで規格 化した不適合元素パターンは海膨軸溶岩とよく似 ている（Sims et al., 2003）。また， Nd, Sr, Hf, $\mathrm{Pb}$ 同位体組成 ${ }^{87} \mathrm{Sr} /{ }^{86} \mathrm{Sr}=0.70244-0.70254$, ${ }^{143} \mathrm{Nd} /{ }^{144} \mathrm{Nd}=0.512387-0.512412,{ }^{176} \mathrm{Hf} /{ }^{177} \mathrm{Hf}=$ $0.283157-0.283194,{ }^{208} \mathrm{~Pb} /{ }^{206} \mathrm{~Pb}=2.063-2.065$ )
も海膨軸溶岩とほとんど変わらない。これらの点 から，オフリッジ溶岩は海膨軸マグマと同じ親マ グマから派生し, 海膨軸直下のマグマ溜りから隔 離された小さなマグマポケットで結晶分化したと 説明されている（Sims et al., 2003）。

北緯 12 度のオフリッジ溶岩は未分化ないしや や分化しており $(\mathrm{MgO}$ 6.42-9.04 wt\%), HFS 
(A)

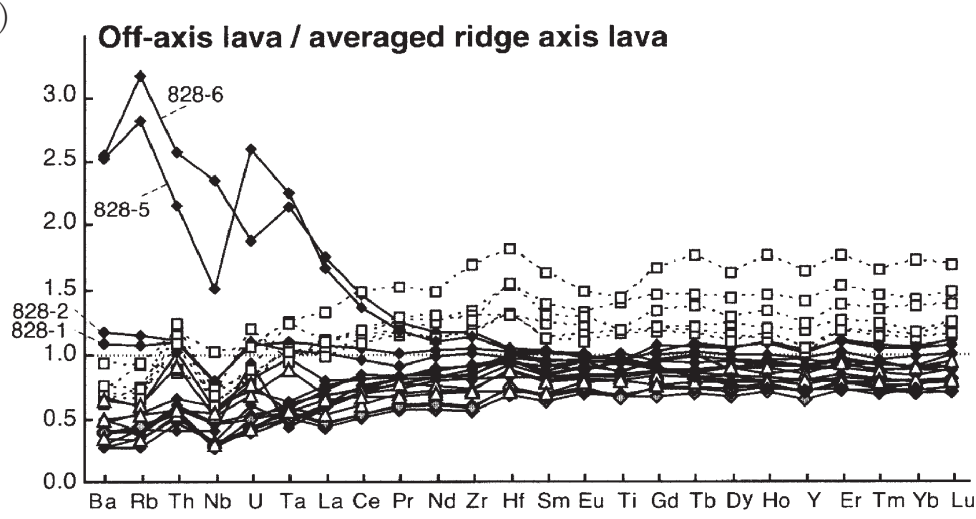

(B)
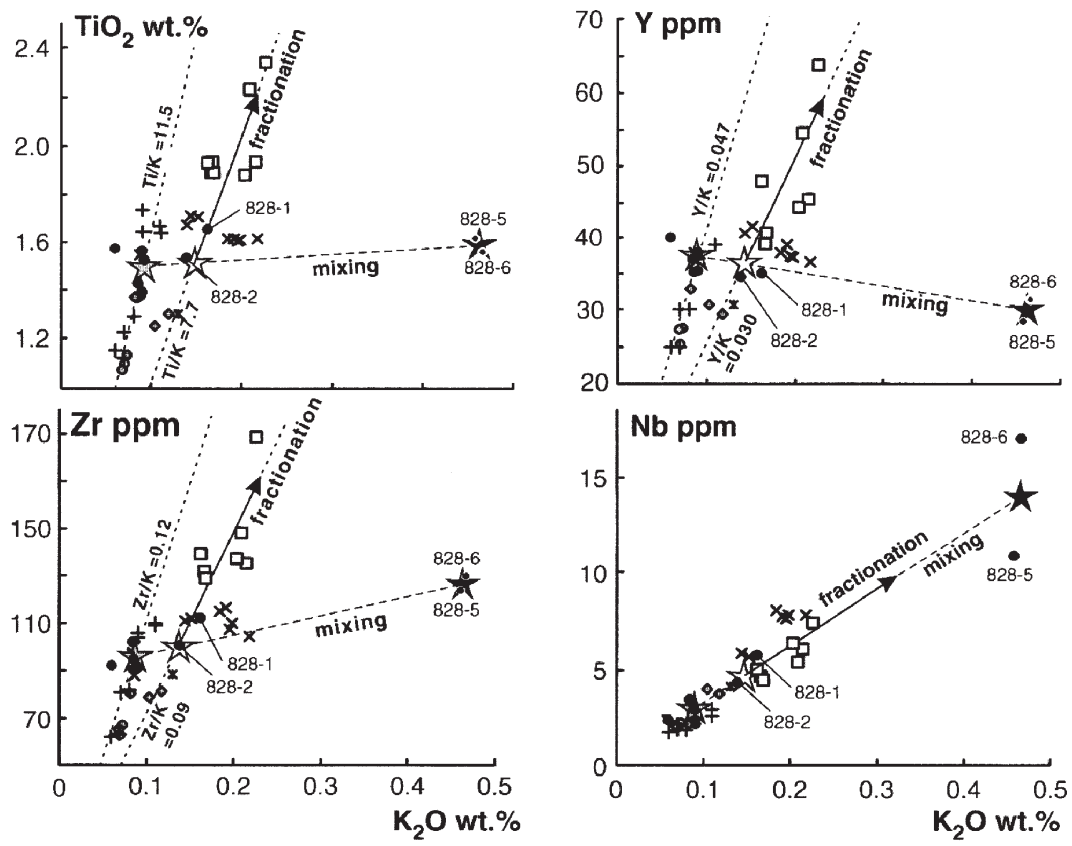

図 $81^{\circ} \mathrm{S}$ 巨大溶岩原の全岩化学組成（Geshi et al., 2007).828-5, 828-6: EMORB,（A）オフリッジ溶岩の組 成を近傍の海膨軸溶岩の平均值で規格化したスパイダーグラム。黒菱形：東海丘，灰菱形：西海丘群, 白四角：中央溶岩原，白三角：北部溶岩ローブ，（B）結晶分化トレンドと混合トレンド。黒丸：東海 丘，灰丸：西海丘群，白四角：中央溶岩原，灰菱形：北部溶岩ローブ, $\times: 14^{\circ} \mathrm{S}$ 海膨軸溶岩と基盤岩， $+: 8^{\circ} \mathrm{S}$ 海膨軸溶岩. 東海丘の EMORB と NMORB の混合線上に TMORB $(828-1,2)$ がある. 中央溶岩 原はTMORB からの結晶分化トレンド上にある.

Fig. 8 Whole rock analyses of the $14^{\circ} \mathrm{S}$ large lava field (Geshi et al., 2007). Two EMORB samples are denoted as 828-5 and 828-6. (A) Incompatible element abundances normalized by the near-by axial lavas. Two EMORB samples are enriched in highly incompatible elements, while TMORB samples from the Central lava plateau show elevated less incompatible elements and depletion in highly incompatible elements. Solid diamond: East cone, grey diamond: West cones, open square: Central lava plateau, open triangle: Northern lobe. (B) Fractional trends shown by the NMORB and TMORB samples from the rise axis and the $14^{\circ} \mathrm{S}$ large lava field. The parent magma of TMORB could be formed by mixing of EMORB and NMORB magmas. Solid circle: East cone, grey circle: West cones, open square: Central lava plateau, grey diamond: Northern lobe, $\times$ : $14^{\circ} \mathrm{S}$ axial and basement lavas, plus : $8^{\circ} \mathrm{S}$ axial lava. 


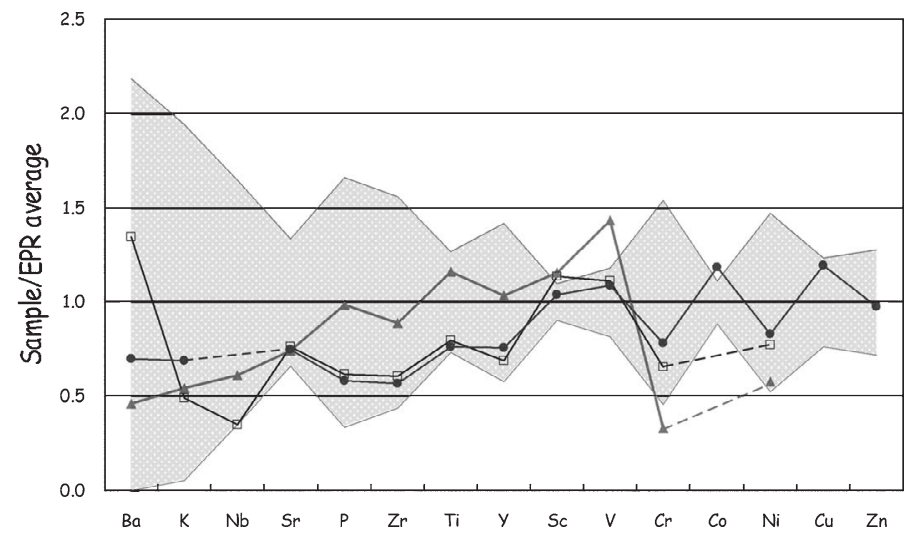

図 9 現在の東太平洋海膨軸南緯 21-23 度の溶岩の平均ガラス組成で規格化した 1256D 孔の全岩化学組成. 現在の海膨軸溶岩について 10 の範囲を網掛けで示した。黑丸：海膨軸で定置した溶岩，黒三角： 溶岩池 (巨大溶岩原), 白四角：その他のオフリッジで定置した溶岩. 1256D の溶岩は現在の海膨軸溶 岩よりもやや枯渴しているが，10の範囲内に収まる。1256D 孔の全岩化学組成は Teagle et al. (2006)

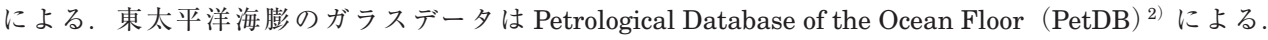

Fig. 9 Element abundances of the core samples from Hole 1256D normalized by the average glass composition from the present EPR between $21^{\circ} \mathrm{N}$ and $23^{\circ} \mathrm{S}$. Grey area represents the average \pm 1 standard deviation for the present axial lavas. Solid circles: axial lava flows, solid triangles: the Lava Pond (Giant flow field), open squares: lava flows emplaced off axis. The 1256D lava compositions are slightly depleted, but are still within the standard deviation of the present EPR lavas. Data sources for the Hole 1256D and the present EPR samples are Teagle et al. (2006) and Petrological Database of the Ocean Floor (PetDB) ${ }^{2)}$.

(High Field Strength) 元素や Ba, Kなどの不 適合元素に枯渇した特徴を示す。 $\mathrm{MgO}$ 量は同じ 範囲内の海膨軸溶岩と変わらないが, $\mathrm{Fe}$ や Ti に そしく，より高い $\mathrm{Mg} \#(48.6-64.2)$ を有する。 多くは NMORB $\left(\mathrm{K}_{2} \mathrm{O} / \mathrm{TiO}_{2}\right.$ 比<0.09) であるが, TMORB $\left(0.09<\mathrm{K}_{2} \mathrm{O} / \mathrm{TiO}_{2}\right.$ 比<0.205) やまれ に EMORB $\left(\mathrm{K}_{2} \mathrm{O} / \mathrm{TiO}_{2}\right.$ 比 = 0.349) もみられる (Reynolds and Langmuir, 2000)。

\section{1-3）火山列と火山脈}

南部東太平洋海膨周辺の火山脈は, 枯渇したも のから肥沃なものまで様々な全岩化学組成を有す る (Donnelley et al., 2003)。一般に西方に分布 する火山ほど軽希土類/重希土類元素組成比やシ リカ不飽和度が高く, マグマの分離深度が梁いこ とを示唆する。 Sojourn Ridge では海膨軸から離 れるにしたがって，すなわち概して古い火山ほど 肥沃な同位体組成を示す傾向がある。これに対し て Brown Ridge では同位体組成は限られた範囲 内にあり，エンリッチした火山が散点的に分布 し，火山脈中の地理的位置とマグマ組成の間に系
統的な関係はみられない。Rano Rahi 火山群が 分布する南緯 17 度付近は東太平洋海膨上の溶岩 に ${ }^{3} \mathrm{He} /{ }^{4} \mathrm{He}$ 比, ${ }^{87} \mathrm{Sr} /{ }^{86} \mathrm{Sr}$ 比, ${ }^{206} \mathrm{~Pb} /{ }^{204} \mathrm{~Pb}$ 比, $\varepsilon \mathrm{Nd}$ の正異常が認められ，同位体的にエンリッ チしたマントル物質が通常の枯渴した NMORB 起源物質中に混在したと考えられている（Mahoney et al., 1994)。

\section{1-4）オフリッジマグマ組成からの制約}

前述のオフリッジマグマの特徵をまとめると次 のようになる。巨大溶岩原と独立単成火山を形成 したマグマは，(1) NMORB 組成が多いが, TMORB P EMORB も同時に産出することが珍 しくない。（2）近傍の軸部溶岩よりも未分化な ものからより分化したものまで, 幅広い組成の溶 岩がほぼ同時期に活動している。（3）近傍の軸 部溶岩よりも不適合元素 (希土類, LIL, HFS) に枯渇したものから富んだものまで組成の変化が 大きいことが多いが, 不適合元素同士の濃度比は ほとんど変わらないこともある(北緯 9 度 50 分)。 (4) 同位体組成は近傍の軸部溶岩と同様である 
(A)
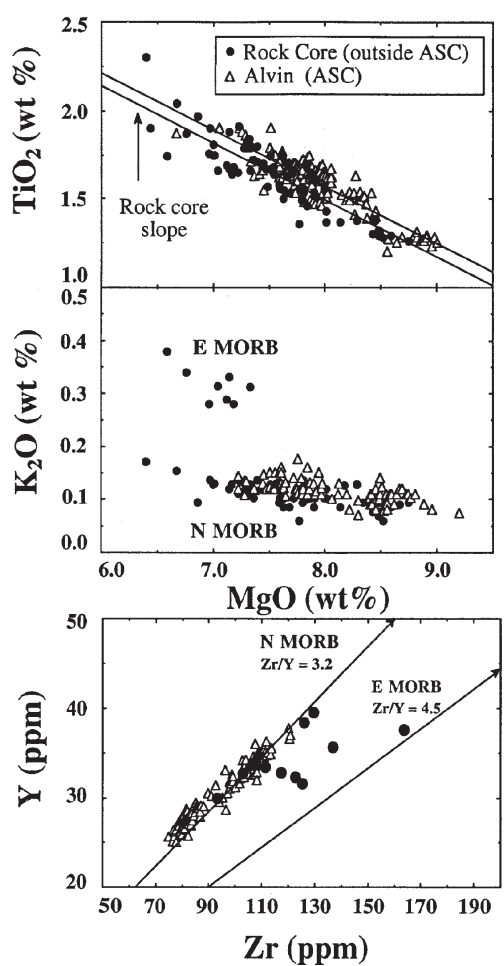

(B)

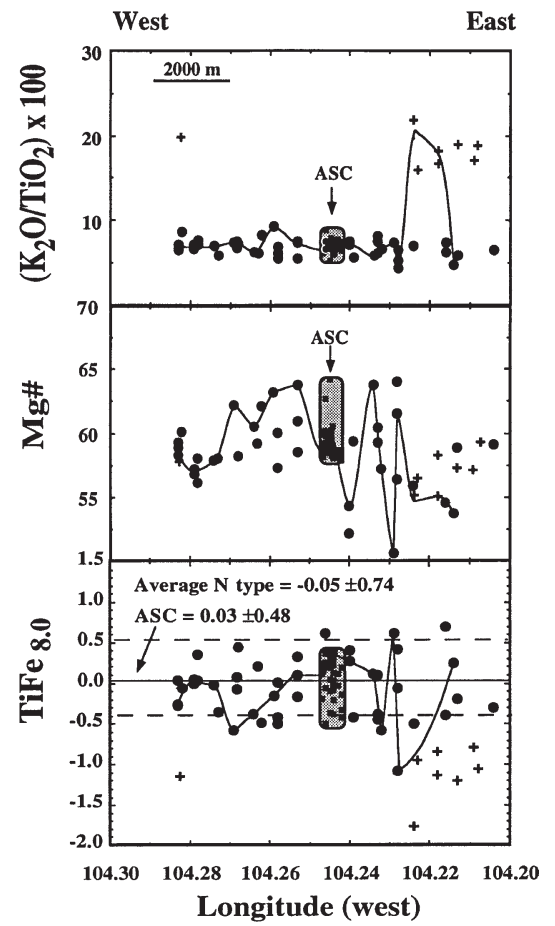

図 10 東太平洋海膨北部のオフリッジ溶岩の全岩化学組成（Perfit et al., 1994）。（A）黑丸：オフリッジ溶岩, 白三角：海膨軸溶岩．オフリッジ溶岩は海膨軸溶岩とオーバーラップするが，前者の方が組成のばら つきが大きく，より分化したものやEMORB を含む。（B）黑丸：オフリッジ溶岩，黑四角（網掛け部 内 $)$ : 海脵軸 $(\mathrm{ASC})$ 溶岩, + ： EMORB. TiFe8.0 $=(\mathrm{FeO} 8.0-10.04)+1.5\left(\mathrm{TiO}_{2} 8.0-1.51\right) . \mathrm{FeO} 8.0$ と $\mathrm{TiO}_{2} 8.0$ は $\mathrm{MgO}$ に対する $\mathrm{FeO}, \mathrm{TiO}_{2}$ の変化図上で $\mathrm{MgO}=8.0 \mathrm{wt} \%$ のときの $\mathrm{FeO}$ と $\mathrm{TiO}_{2}$ の值を表す. $\mathrm{FeO} 8.0$ と $\mathrm{TiO}_{2} 8.0$ の平均値はそれぞれ 10.04 と 1.51 で, $\mathrm{TiFe} 8.0$ は $\mathrm{FeO} 8.0$ と $\mathrm{TiO}_{2} 8.0$ の平均值からの偏 差の重み付き総和で，それぞれの溶岩試料の分化の程度を補正した親マグマのばらつきを示す尺度 として使われている（詳しくは Perfit et al.（1994）を参照）．海膨軸の東 2-4 km に EMORB が多く出 現する。

Fig. 10 Off-ridge lava compositions from the northern EPR at $9^{\circ} 30^{\prime} \mathrm{N}$ (Perfit et al., 1994). (A) Solid circles: offridge lava, open triangles: axial lava. The off-ridge lavas overlap the axial lavas, but the former have more differentiated NMORBs and EMORBs. (B) Solid circles: off-ridge lava, solid squares in the grey shaded area: axial lava, pluses: EMORB. TiFe8.0 $=(\mathrm{FeO} 8.0-10.04)+1.5\left(\mathrm{TiO}_{2} 8.0-1.51\right)$. FeO8.0 and $\mathrm{TiO}_{2} 8.0$ represent the $\mathrm{FeO}$ and $\mathrm{TiO}_{2}$ contents at $\mathrm{MgO}=8.0$ wt $\%$ on $\mathrm{MgO}$ vs. $\mathrm{FeO}$ and $\mathrm{TiO}_{2}$ variation diagrams, respectively. The averages of $\mathrm{FeO} 8.0$ and $\mathrm{TiO}_{2} 8.0$ are 10.04 and 1.51, respectively. TiFe8.0 is used as an indicator of the diversity of the parent magmas. See Perfit et al. (1994) for details. Note that EMORB lavas are preferentially present on the Cocos Plate (east of the rise axis).

場合と，若干異なるものを含む場合がある。 EMORB は同位体的にもエンリッチしているこ とがある。（5）近傍の軸部溶岩とは異なる親マ グマに由来することが多い。部分溶融程度の違い で生じた場合と（ $8^{\circ} \mathrm{S}$ 巨大溶岩原），それぞれ独 立に生じた NMORB と EMORB の混合によって
生成された場合がある（14 $\mathrm{S}$ 巨大溶岩原）。

共通の親マグマから結晶分化程度の違いで生じた ものがある（北緯 9 度 50 分）。（7）巨大溶岩原 は大量の分化した溶岩を短期間に噴出している。 これは結晶分化する場として平均的な AMC（海 膨軸下マグマ溜り）の少なくとも 100 倍の体積 
を持つマグマ溜りを必要とする。（8）独立単成 火山と巨大溶岩原の分布は，20万年以内の基盤 岩上に限られ，東太平洋海膨の両翼にほぼ対称に 出現する。

火山列㧍よび火山脈については，(1）独立単 成火山よりもオフリッジに出現し, 数 $100 \mathrm{~km}$ 以 上離れた場所でも成長する。(2) 東太平洋海澎 の太平洋プレート側に偏在し, 特に南太平洋に集 中する。（3）軸部溶岩が同位体的にエンリッチ した南緯 17 度付近では，火山列・火山脈にも同 様にエンリッチした成分の寄与が認められる。

Perfit et al.（1994）は北緯 9 度 30 分の EMORB マグマはオフリッジだけではなく，海膨軸部にも 時折供給されていると考えた。AMCに供給され た EMORB は量的に多い NMORB マグマと混合 するために，海膨軸部では EMORB マグマの存 在を検出することは難しい。しかし，オフリッジ では AMC を経ずに噴火するために, EMORBが 出現しやすい。一方, 同位体的にエンリッチした $17^{\circ} \mathrm{S}$ 軸部溶岩の成因について, Mahoney et al.（1994）は NMORB 起源物質である枯渇した マントル上昇流にプルーム的な同位体組成を有す る物質が取り込まれて融解したと考えた。

以上の観察と解釈を基にオフリッジ火山を形成 したマグマの起源について次のような仮説を考え る：枯渴した NMORB 成分とエンリッチした EMORB 成分を取り达んだマグマはそれぞれマ ントル中で発生する。これらの端成分マグマは, マントル〜地殼中の上昇経路と混合比の違いによ り, 最終的に NMORB, TMORB, EMORB マ グマとなった。上昇経路の違いから EMORB は 軸部よりもオフリッジに出現しやすい。また, NMORB と EMORB が混合して TMORB となっ て海膨軸やオフリッジで噴火する。このモデルに よれば， $\mathrm{AMC}$ やそ下に続く下部地殼部分溶融 帯はオフリッジ火山の供給源としては考えにく い。その他のマグマ供給源としてどのようなもの があり得るであろうか。次節以降で地球物理学的 観測と構造上の観点から，オフリッジ火山の供給 源について考察する。

\section{2）独立単成火山と巨大溶岩原の供給源}

独立単成火山, 巨大溶岩原の出現はともに海膨 軸の近傍 20 万年前（片側拡大速度が $8 \mathrm{~cm} / \mathrm{yr}$ で あれば，海膨軸から $16 \mathrm{~km}$ ）までの基盤上に限 られ，海膨軸に平行な割れ目系を給源火口として いる。この分布域は海膨斜面から山麓にあたり, 正断層系が発達する領域である。地殼内の脆性一 塑性境界はモホ面と $\mathrm{AMC}$ およびその下部に広が る高温の深成岩体内にあると考えられる。この境 界は海膨軸を中心に高く盛り上がっているので, 脆性地殼は重力の作用によって境界面上を滑り落 ち，地款内に引張応力を発生することが期待され る。また, AMC 直下の深成岩体が固結して側方 のプレートに付加し, 冷却とともに地殼を下方に 引きずるために海膨山麓は上に向かって凹型にた わみ，これが海膨軸から離れるにしたがって水平 に戻るために地殼上部に断層を生じる（unbending; Buck, 2001)。海膨軸周辺のオフリッジ火山 は，このプレート拡大方向に作用する最小圧縮応 力場の下で生じた割れ目系を利用して噴火したと 考えられる。

東太平洋海膨の北緯 9 度付近の地震波卜モグ ラフィーによると, モホ直下では幅 10 数 $\mathrm{km} に$ 及ぶ範囲でマントルに部分溶融が認められる（図 11; Dunn et al., 2000; Crawford and Webb, 2002)。したがって，これらのオフリッジ火山の マグマ発生源としてプレート拡大境界のマントル 上昇流が考えられる。マントルで発生したマグマ は, AMC, 下部地殼中のシル (Boudier et al., 1996; Korenaga and Kelemen, 1997; Kelemen et al., 1997), 海膨軸直下〜オフリッジのモホ遷 移帯 Moho Transition Zone (MTZ) (Boudier and Nicolas, 1995; 荒井・阿部, 2003; Sohn and Sims, 2005）に蓄えられ，オフリッジ火山のマグ マ供給源となった可能性がある。

\section{2-1）海膨軸直下のマグマ溜り（AMC）}

1980 年代に北緯 9-13 度において行われた地 震波探査の結果, 東太平洋海膨軸直下 $1-1.5 \mathrm{~km}$ にマグマ溜りの上面を示す強い反射面があり，そ の下に厚さ 4-5 km の低速度領域が広がる速度構 造が得られた (Harding et al., 1989; Toomey et 
(A)
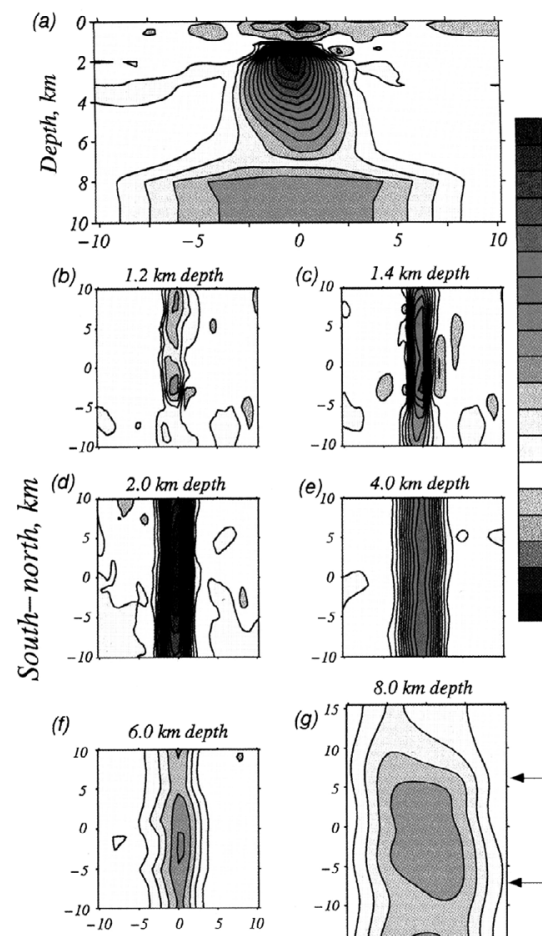
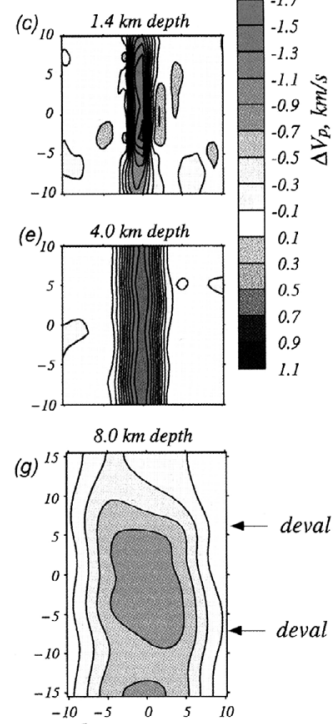

(B)
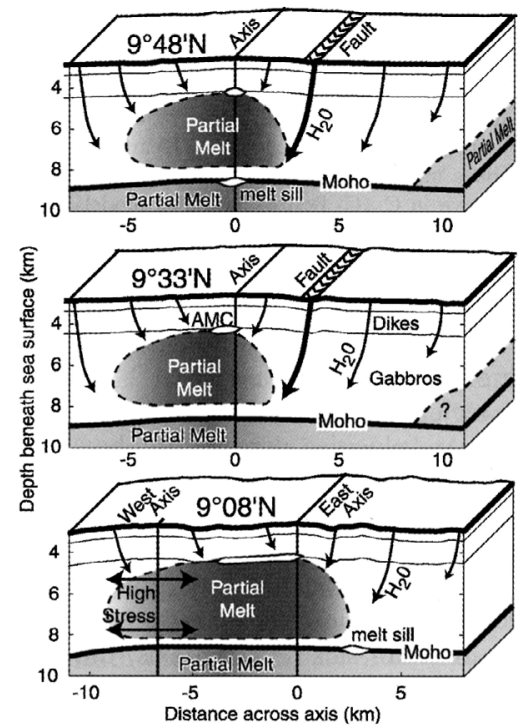

West-east, $\mathrm{km}$

図 11 (A) 東太平洋海膨北緯 9 度 30 分の地震波卜モグラフィー (Dunn et al., 2000). 海膨軸の横断面と海底 面下 1.2-8 km の水平断面を示す。（B）海底 compliance と地震波速度構造に基づく東太平洋海膨北緯 9 度 48 分-08 分のメルト分布 (Crawford and Webb, 2002).

Fig. 11 Seismic tomography of the EPR $9^{\circ} 30^{\prime} \mathrm{N}$ (Dunn et al., 2000). Across axis and subhorizontal sections from $1.2 \mathrm{~km}$ to $8 \mathrm{~km}$ in depth are shown. (B) Melt distribution beneath the EPR $9^{\circ} 48^{\prime}-08^{\prime} \mathrm{N}$ based on seafloor compliance and seismic velocity structures (Crawford and Webb, 2002).

al., 1990; Vera et al., 1990)。これらを元に Sinton and Detrick（1992）は厚さ 100-200 m のレ ンズ状マグマ溜りを頂点としてその下に厚い結 晶ーマッシュ層があり，それを取り巻いてわずか にメルトを含むガブロが海膨軸の外側〜 $10 \mathrm{~km}$ にまで広がる構造モデルを提唱した。このモデル によれば，海膨軸周辺の下部地殼にはかなりの範 囲にわたってマグマが存在することが期待され る。その後, Dunn et al. (2000) は北緯 9 度の 地震波卜モグラフィーの解析をやり直し，下部地 殼〜モホ遷移帯における詳細なメルト分布を示し た（図 11A）。それによると，海膨軸直下には鉛 直に延びる幅 $4 \mathrm{~km}$ ほどの低速度領域があり，拡
大軸から $2 \mathrm{~km}$ 以上離れた地殼は低温で固結して おり，Sinton and Detrick（1992）に描かれたよ うな幅広い部分溶融域は存在しない。Crawford and Webb（2002）は北緯 9 度 48 分-08 分の東 太平洋海膨軸を横断する 3 測線に沿って海水の 振動 (ocean gravity wave loading) によって引 き起こされる海底面の compliance 測定から $\mathrm{S}$ 波 速度構造を求め, $\mathrm{P}$ 波速度構造と比較することに よって地殼〜マントル上面付近のメルト分布を推 定した。それによると，セグメント中心の北部か ら重複拡大海嶺がある南部に向けて地殼およびマ ントル上面の部分溶融帯の中心は拡大軸の西に $3 \mathrm{~km}$ 以上も片寄ると同時に, AMC と下部地殼 
の部分溶融帯の幅が $2-4$ 倍に広がることが判明 した（図 11B）。海膨軸下の非対称なメルト分布 から，オフリッジで発達した地殼深部にまで達す る断層系にそった激しい熱水循環によって地殼中 のメルト分布が規制されていると考えられる (Crawford and Webb, 2002; Maclennan et al., 2005)。そのため, 地殼中のメルトの存在は $\mathrm{AMC}$ とその下の幅 $4 \mathrm{~km}$ 以下の狭い領域内に限 られる。ところが，オフリッジの巨大溶岩原や独 立単成火山を生じる場は海膨軸から 20 万年前ま での基盤（<15 km）に広がっており，AMCか ら供給されたとは考えにくい。また，南緯 14 度 やサイト 1256 のように分化した溶岩からなる巨 大溶岩原は，大量のマグマを蓄え，結晶分化する 場として $10 \mathrm{~km}^{3}$ オーダーのマグマ溜りを必要と する。しかし，東太平洋海膨の $\mathrm{AMC}$ の体積は 高々 0.05-0.15 km $\mathrm{km}^{3}$ 程度であり (Singh et al., 1998)，地殼浅部の AMCに $10 \mathrm{~km}^{3}$ を超えるマ グマを蓄えることは難しい。観測に基づく個々の 噴火の推定噴出量と地殼の厚さ, プレート拡大速 度の関係から, 東太平洋海膨では 2 年に 1 度の頻 度で $0.001 \mathrm{~km}^{3}$ オーダーの噴火があると考えられ る（Perfit and Chadwick, 1998)。これはプレー 卜拡大に伴って上部地殼の差応力が急速に増加す るために，大量のマグマを蓄積する間もなく容易 に岩脈貫入や噴火が発生するからである (Umino, 2006)。

\section{2-2）下部地殼のシル状マグマ}

東太平洋海膨北緯 9 度の AMC 直下には幅 $4 \mathrm{~km}$ の $\mathrm{P}$ 波低速度異常領域が存在し, 少量のメ ルトを含む部分溶融帯と解釈されている（Dunn et al., 2000)。P 波速度が地殼深部ほど速くなる ことから，下部地殼深部にはメルトはほとんど存 在しないと考えられる（Dunn et al., 2000）。一 方, 高速拡大系であったオマーンオフィオライト では，下部地殼の主体は層状ガブロである。層内 の結晶粒径分布が上下対称であったり，明瞭な貫 入関係が観察されること, MTZ 中のガブロシル と同じ鉱物組合せ・組成を有することから，ほぼ 水平に貫入したシル群として形成されたとする説 が有力である (Boudier et al., 1996; Kelemen et al., 1997; Korenaga and Kelemen, 1997)。下部 地殼全体のメルト量が 7\%のとき, 溶融状態のシ ルとして下部地殼中にメルトが局在化した場合 は，連結したメルトチャンネルが平均的に分散し た部分溶融帯に比べて地震波速度の低下はわずか 6 分の 1 でしかない (Crawford and Webb, 2002)。 すなわち, 下部地殼深部において地震波速度が上 昇するのはメルトが少ないからではなく，下部地 殼中に孤立するシル状マグマ溜りにメルトが局在 化しているためである可能性がある。部分溶融度 $2.5 \%$ の厚さ $4 \mathrm{~km}$ の下部地殼に含まれるメルト の総量は, 同じ幅で厚さ $100 \mathrm{~m}$ の AMC のメル 卜量に等しい。下部地殼部分溶融帯は必ずしも拡 大軸直下にあるわけではないので，拡大軸の片側 に偏在した部分溶融帯であればオフリッジ火山の 給源となりうる。しかしながら, 南部東太平洋海 膨では独立単成火山は拡大軸の両翼に対称に分布 しており（White et al., 1998），下部地殼内に AMC の幅を大きく超えたシル状マグマ溜りが存 在するか, 10 万年以下の短いタイムスケールで 海膨軸の両翼間を部分溶融帯が移動しない限り説 明がつかない。また，オマーンオフィオライトで は層状ガブロは AMC が固結したと考えられる上 部ガブロよりも未分化な組成をしており（Kelemen et al., 1997; MacLeod and Yaouancq, 2000)，巨 大溶岩原をつくる大量の分化したマグマを供給し たシルが下部地殼に存在したとは考えにくい。

\section{2-3）モホ遷移帯 MTZ}

オマーンオフィオライトではかつての下部地殼 であった層状ガブロからマントル構成物と考えら れるカンラン岩テクトナイトへの岩相変化は漸移 的であるため，モホ遷移带（Moho Transition Zone: MTZ) と呼ばれている（Nicolas, 1989; MTZについては，本特集号の荒井・阿部 (2008)，小澤（2008）も参照されたい)。MTZ では層序的に上位から下位に向かってダナイト優 勢の母岩中にトロクトライトやカンラン石ガブロ のシルを挟んだ岩相，ハルツバージャイト中にダ ナイトやトロクトライト，（カンラン石）ガブロ がシル，岩脈あるいはネットワーク状に貫入した 岩相を経て, 次第にハルッバージャイトが優勢と 
なり，マントル岩に移行する（Boudier and Nicolas, 1995; 上杉ほか, 2003)。ダナイト中には クロムスピネルが集積したクロミタイトポッドも 散見される。同様の産状を示す岩相はHess Deepの掘削コアや Mid-Cayman Trough のド レッジ試料で詳細に調べられており（Arai and Matsukage, 1996; Arai et al., 1997)，前者では $90 \mathrm{~m}$ 以上にわたって MTZ の岩相が掘削された。 また，南西インド洋の Atlantis Banks では「し んかい 6500」による潜水調査で MTZ（厚さ< $40 \mathrm{~m} ）$ のその場観察が行われ，レールゾライト 中にハルツバージャイトやガブロを伴ったダナイ 卜を挟在する岩相と層状ガブロの境界が確認され た（松本ほか, 2003）。MTZ は拡大速度が大きい ほど厚く発達するが，南西インド洋海嶺のように 超低速拡大海嶺でも薄くなるだけで基本的な構成 は変わらない（荒井・阿部, 2003）。

オマーンオフィオライトの MTZ は厚さ数 $\mathrm{m}$ から $1 \mathrm{~km}$ 近くにもなるが，一般に古拡大軸のセ グメント中心で厚く, セグメント端へ向けて薄く なる（Benn et al., 1988; Nicolas, 1989）。また, 拡大軸直下で厚く，オフリッジに移動するにつれ て塑性変形によって引き延ばされ薄化する $(\mathrm{Nico}-$ las, 1989; Boudier and Nicolas, 1995)。拡大中 の海嶺軸を含むリソスフェアがそのまま衝上した とされるオマーン南部の Maqsad ダイアピル直上 では, MTZ は厚さ 500-750 $\mathrm{m}$ に達する（Boudier and Nicolas, 1995)。これに対してオフリッジの リソスフェアが衝上した北部オマーン山脈では MTZ の厚さはセグメント中心で $300 \mathrm{~m}$, 同じセ グメントの端では 150-30 m と急激に薄くなる (Adachi and Miyashita, 2003)。一方，地殼はセ グメント中心で薄く, セグメント端へ向けて厚く なる（Nicolas et al., 1996）。同様の観測は東太 平洋海膨北緯 9-13 度で知られており, セグメン ト中心よりも北緯 9 度 08 分の重複拡大軸で地殼 が厚くなる（Barth and Mutter, 1996)。これは 2 つの拡大軸の間では剪断と引張応力が集中する ので，より多くのマグマが地殼中に貫入しやすい ためと説明されている (Crawford and Webb, 2002)。
MTZ はアセノスフェア中を上昇するマグマと マントルカンラン岩の大規模な反応帯と考えられ ている (Kelemen et al., 1995, 1997, 2000; 上杉 ほか, 2003; 小澤, 2005, 2008)。そこではマグマ と反応したハルツバージャイト中の斜方輝石が非 調和融解してカンラン石と新たな液を生じる。天 然の玄武岩マグマ-ハルツバージャイト系では融 解する斜方輝石と晶出するカンラン石の質量比は およそ 1.4:1 となる (Kelemen, 1990)。海嶺下 の部分溶融したマントル中の割れ目を上昇する立 武岩マグマは, 壁岩のカンラン岩と反応してダナ イトを形成しつつ, 自らの液組成をよりシリカに 飽和した方向へ変化させていく。このような反応 を経て最終的に地殼へ到達したマグマは, MTZ ダナイトと平衡な組成を有する (Kelemen et al., 1995, 1997; Korenaga and Kelemen, 1997)。晶 出したカンラン石によって母岩の孔隙率が下がる と, やがてマグマとカンラン岩の接触が絶たれ, 斜方輝石の非調和融解は起こらなくなる。さらに 冷却に伴って岩脈中のマグマの結晶分化が進行す ると，最終的には $\mathrm{K} や \mathrm{Ti}$ などの不適合元素が残 液中に濃集し，角閃石や金雲母などの含水鉱物が 晶出する。したがって, MTZ 中にはダナイトと 共存しうる $\mathrm{Mg} \#$ の高い未分化マグマから含水鉱 物を晶出する分化したマグマまで幅広い組成のマ グマが同時に存在している可能性がある。また, 軽希土類元素や LIL 元素, HFS 元素などの不適 合元素に富む分化したマグマや流体に污染された ダナイトがMTZに残される（Arai et al., 1997; Arai, 2005)。

下部地殼のマグマを含む部分溶融帯に比べて, MTZ の部分溶融帯は数倍の広がりを持っている。 東太平洋海膨の北緯 9 度の地震波卜モグラフィー は MTZに AMC の 1.4 倍ものマグマが存在する ことを示唆する（図 11A; Dunn et al., 2000）。 また, 北緯 9 度 48 分と 33 分では, 海膨軸の東 10-14 km の下部地殼〜 MTZ 付近に分布するメ ルトが観測されている。（図 11B; Crawford and Webb, 2002)。同様の観測結果は北緯 12 度で早 くから得られていた（Garmany, 1989）。海膨軸 下で供給され，軸上で貫入，噴出しなかった余剩 
のマグマは，MTZに蓄えられたままオフリッジ に運ばれる間に結晶分化〜固化が進行する。一 方，上昇するアセノスフェア中で発生したマグマ のすべてが拡大軸直下の MTZ を経て AMC へ収 束するわけではない。拡大軸から離れて側方に流 れていくアセノスフェアを一部のマグマは横切る ように上昇し，オフリッジでリソスフェア下の MTZ に到達する。リソスフェアの底面は拡大軸 へ向かって上り傾斜となっているので，マグマは MTZ伝いに拡大軸へ向かって移動する（図 12; Spiegelman and McKenzie, 1987; Spiegelman and Reynolds, 1999; Sohn and Sims, 2005)。 プ レート拡大に伴って受動的に誘因されたマントル 対流では，拡大軸下で上昇したマグマに比べてオ フリッジマグマの方が不適合元素に枯渇すると予 想される (Spiegelman and Reynolds, 1999)。 一方，MTZにトラップされた分化マグマや污染 されたダナイトなどは, LIL 元素などの不適合元 素に富んでいる。オフリッジマグマと MTZ マグ マの混合や，污染されたダナイトとの反応・同化 の程度によって，枯渇したマグマから肥沃なマグ マまで幅広い組成のマグマを生じることが期待さ れる。 $14{ }^{\circ} \mathrm{S}$ 巨大溶岩原の主体をなす中央溶岩平 原は，最も分化していながら $\mathrm{K} ， \mathrm{Ti}$ ，希土類元素 濃度が中間的で, NMORB と EMORB の混合に よって生じたとされている（Geshi et al., 2007）。 このような混合マグマの生成は MTZ 通過する オフリッジマグマに期待される普遍的な現象と考 えられる。

プレート拡大に伴う歪みは拡大軸の近傍で断層 やマグマ貫入によって解消されるので，オフリッ ジで脆性地殼に作用するのはリソスフェアの冷却 やオフリッジ火山の荷重によって発生する等方的 な応力である (Hieronymus and Bercovici, 2000; Sohn and Sims, 2005)。オフリッジにおけるリ ソスフェアの冷却に伴う歪み速度は時間の平方根 で効いてくるから，プレート拡大に起因する拡大 軸付近の歪み速度に比べてはるかに小さい。した がって, リソスフェアの破壞強度に達する前に, MTZ に大量のマグマを蓄積することは十分可能 と思われる。巨大溶岩原の多様なマグマ組成を説
(A)

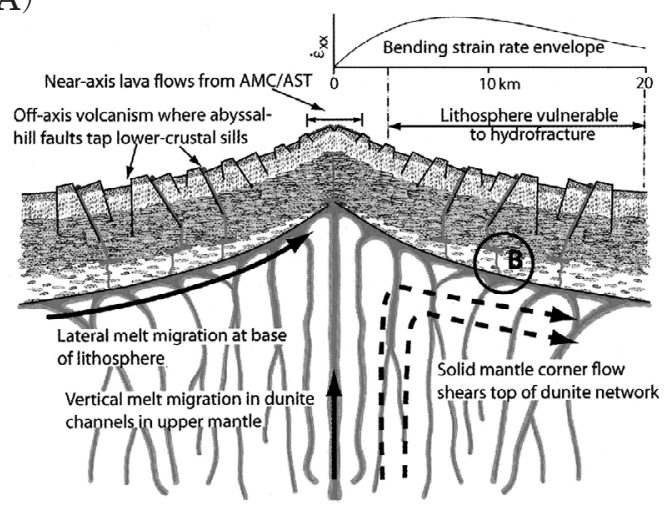

(B)

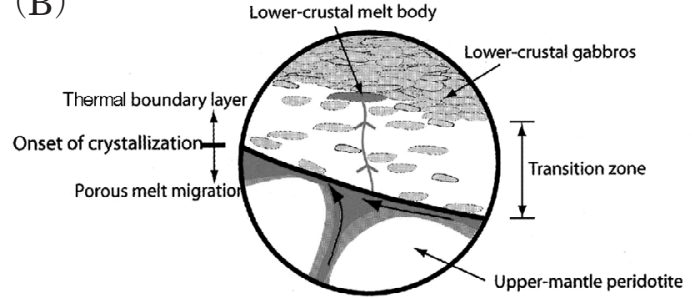

図 12 高速拡大海嶺下のアセノスフェアの流れ とマグマの上昇経路を概念的に表したモ デル (Sohn and Sims, 2005). (A)オフリッ ジで上昇したマグマはリソスフェアの底 に沿って拡大軸方向へ移動する。(B) 拡 大軸に到達する前にMTZでマグマ溜り を形成し，オフリッジで噴火するものも ある。

Fig. 12 Asthenospheric flow and magma paths beneath a fast-spreading ridge (Sohn and Sims, 2005). (A) Magma ascends to the base of the lithosphere and flows toward the ridge axis. (B) Off-ridge magma chambers form within the MTZ and extrude far off axis.

明できることに加え，ゆっくりとした温度低下と 十分なマグマ収容能力を有する点で, MTZ は才 フリッジ火山のマグマ供給源の最有力候補と言え る。1256D 孔で推定された上部地殼の密度分布 （Umino, 2006）を参考に, 海洋地殼の平均密度 を $2850 \mathrm{~kg} / \mathrm{m}^{3}$, マグマの密度を $2700 \mathrm{~kg} / \mathrm{m}^{3}$ とす ると, 厚さ 5.5-6 km の地殼を貫いて地表にまで 達した岩脈先端のマグマ頭位には 8-9 MPa もの 高い余剩圧がかかることになる。これは，一担地 表にまで達する割れ目が発生すると，蓄えられた 
マグマのほぼすべてが噴出するであろうことを意 味する。すなわち，海膨軸下で供給されたマグマ がMTZに一時的に蓄えられたとしても，遠いオ フリッジまで残存する機会は少ないと思われる。

\section{3）火山列と火山脈を形成したオフリッジ マグマの起源}

火山列と火山脈はよりオフリッジで活動し，海 膨軸から数 $100 \mathrm{~km}$ 以上も離れて成長を続ける。 プレート拡大方向に延びる配列は，同方向の割れ 目系の存在を示唆する。これらの拡大軸から遠く 離れたマグマの起源は, アセノスフェアで発生し た局所的あるいは地域的な上昇流が考えやすい (Scheirer et al., 1996; Donnelly et al., 2003; Forsyth et al., 2006)。候補として, 拡大軸方向 に流れるアセノスフェア反流 (Forsyth et al., 2006), リソスフェアーアセノスフェア境界層で 発生する小規模な対流 (Buck and Parmientier, 1986; Haxby and Weissel, 1986)（図 13）やホッ トスポット起源のプルーム (Scheirer et al., 1996）などが考えられる。

線状配列した火山列や火山脈を生じた原因とし て，プレートに作用する広域的な引張応力を挙げ ることができる (Sandwell et al., 1995)。しかし， リソスフェアの割れ目に吸い上げられたアセノス フェアが減圧溶融を起こすためには $10 \%$ 程度の リソスフェアの拡大が必要とされるが，火山活動 に先立って既存の断裂帯が拡大したり，新たな割 れ目系が発達した痕跡は火山脈周辺の基盤上に認 められない（Forsyth et al., 2006）。一方，拡大 軸から離れていくリソスフェアの冷却に伴って, 収縮割れ目が発生し，リソスフェア下にあったマ グマが噴出したというモデルがある（Sandwell and Fialko, 2004)。リソスフェア下底が $800^{\circ} \mathrm{C}$ になったときに割れ目が発生する場合，約 $8 \mathrm{Ma}$ でリソスフェアの厚さは $20 \mathrm{~km}$, 生じる割れ目 の幅はおよそ $280 \mathrm{~m}$ となることが期待される。 割れ目中をマントルカンラン岩が $1 \mathrm{~km}$ 上昇する ごとに $0.4 \%$ 断熱融解すると $7.5 \times 10^{4} \mathrm{~m}^{3}$ のマ グマを生じることになる（Forsyth et al., 2006）。 これは, 幅 $1 \mathrm{~km}$, 高さ $150 \mathrm{~m}$ 程度の火山脈の体 積に相当し, Hotu Matua の西方や Sojourn Ridge
の北に分布するような小規模の火山脈はリソス フェア収縮割れ目モデルで説明しうる。しかし, Sojourn Ridge や Puka Puka Ridge のような大 規模火山脈を形成した大量のマグマの発生や，火 山脈に沿った西から東への活動中心の移動，プ レート拡大方向に平行な配列などは，収縮モデル では説明し難い。

Forsyth et al.（2006）はリソスフェア直下に 海膨軸へ向かって流れる不均質なアセノスフェア 反流の存在を提唱した。リソスフェアは拡大軸に 向かって薄くなるので, リソスフェア底に沿って 流れるアセノスフェア反流が海膨軸に近づくにつ れて融けやすい部分から選択的に減圧溶融を起こ すことが期待される。発生したマグマは部分溶融 した反流中の粘性の不均質によって，次第にいく つかのチャンネルに収束し, 線状のマグマ供給源 となる。一方，リソスフェア底部の温度境界層が 冷却するにつれて不安定となり，小規模な対流を 生じ，その中でマグマを発生するというモデルもあ る (Buck and Parmientier, 1986; Korenaga and Jordan, 2003)。どちらのモデルもマグマの発生 は海膨軸から離れたところから始まり，海膨軸へ 向かって進行するので, 火山脈の活動中心の移動 は説明可能である（Forsyth et al., 2006）。活動 初期にはやや広い範囲に分散した小火山群の形成 が行われるが，火山群が成長するにつれて隣接し た火山群との間に荷重による応力場が作用して, 次第に線状配列した火山列から火山脈へと進化し ていくことが考えられる (Hieronymus and Bercovici, 2000)。

ところで, Rano Rahi 火山群は西方の南太平 洋スーパープルームに向かって収束していくこと から，ホットスポット起源のプルームが直接の EMORB マグマの供給源とは考えにくい。ただ し，南太平洋スーパープルームからの物質供給が 皆無であるとする積極的な根拠はないように思わ れる。火山列や火山脈が太平洋プレート側に偏在 していることは，少なくとも熱源としてのスー パープルームの影響が考えられる (Scheirer et $a l .$, 1996)。太平洋プレート下のアセノスフェア が高温であるために，ナスカプレートに比べて太 
(A)

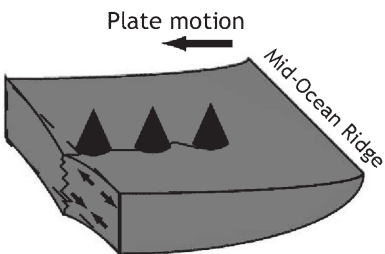

(B)

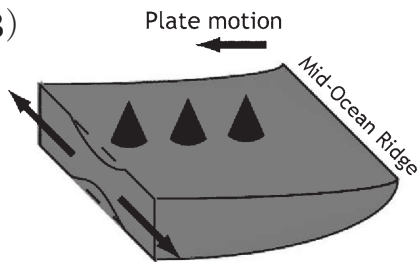

(C)

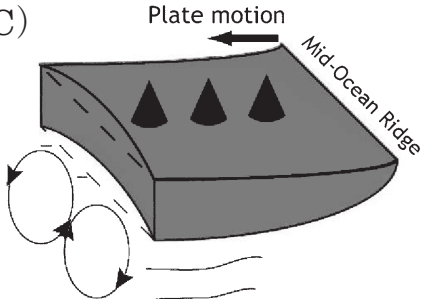

Plate motion

(D)

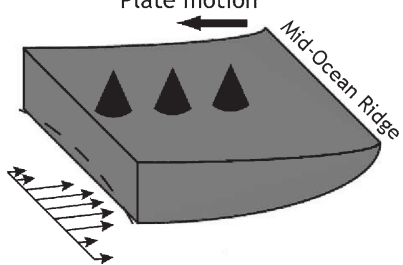

図 13 火山列のマグマ発生モデル（Harmon et al., 2006).（A）プレートの冷却収縮とオフリッジ火山の荷重 によるたわみによって割れ目を生じ，火山列となる，(B) プレートの南北拡大によって薄くなった リソスフェアの弱線に沿って噴火する，（C）冷却するプレート下面と接するアセノスフェア中の温 度境界層が不安定になって対流を起こし，マグマを発生する，（D）拡大軸に向かって上昇するアセ ノスフェア反流がいくつかのチャンネルに収束して断熱融解し，火山脈を生じる。

Fig. 13 Sketches showing the generation of a volcanic chain (Harmon et al., 2006). (A) The thermoelastic flexure and bending of the lithosphere due to the load of off-ridge volcanoes cause cracking of the lithosphere.

(B) Lithospheric extension and boudinage. (C) Small-scale convection induced by the unstable thermal boundary layer beneath cooling lithosphere. (D) Adiabatic melting within the asthenospheric return flow toward the rise axis.

平洋プレートの沈降速度が著しく遅く，マントル 中の部分溶融帯は海膨軸から西に偏在している (Perrot et al., 1998; Baba et al., 2006)。そのた めに太平洋プレート下ではアセノスフェアの流動 が活性化し，過剩なマグマを生じやすい状態にあ ると考えられる。

\section{IV. 終わりに}

本論では「東太平洋海膨周辺に数多く存在する オフリッジ火山がどこから来たのか」という問題 に焦点をあてて, 特にモホ遷移帯の役割とその重 要性に関するこれまでの研究成果と著者らの作業 仮説を紹介した。現在，われわれは $14^{\circ} \mathrm{S}$ 巨大溶 岩原を中心に南部東太平洋海澎のオフリッジ火山 を再訪し, 電磁気学的構造探査や岩石学的 ·地球 化学的研究をはじめとする詳細な調査を行うこと を計画している。近い将来，この調査研究を通じ て著者らの作業仮説を検証するとともに，「モホ とは何か」という問いかけに対していささかなり
とも明快な回答を与えられるように力を尽くした いと思っている。

\section{謝 辞}

本論を執筆する機会を与えていただいた笠原順三先 生をはじめ編集委員の皆様, 原稿の不備を指摘し, 建 設的なコメントを頂戴した荒井章司氏，丸山茂徳氏に 御礼申し上げます。

\section{注}

1) Global Multi-Resolution Topography (GMRT) Synthesis : http://www.marine-geo.org/services/ google/create_merc_map.php [Cited 2007/09/19].

2) Petrological Database of the Ocean Floor (PetDB): http://www.petdb.org/petdbWeb/about.jsp [Cited 2003/03/08].

\section{文献}

Adachi, Y. and Miyashita, S. (2003): Geology and petrology of the plutonic complexes in the Wadi Fizh area: Multiple magmatic events and segment structure in the northern Oman ophiolite. Geochemistry, Geophysics, Geosystems, 4, 8619, doi:10.1029/2001 
GC000272.

Alexander, R.T. and Macdonald, K.C. (1996): Small off-axis volcanoes on the East Pacific Rise. Earth and Planetary Science Letters, 139, 387-394.

Arai, S. (2005): Role of dunite in genesis of primitive MORB. Proceedings of Japan Academy, Series B, 81, 14-19.

荒井章司・阿部なつ江 (2003): 海洋マントルの岩石学 的構造と海洋掘削. 地学雑誌, 112, 692-704.

荒井章司・阿部なつ江 (2008): モホの岩石学的実体を 探る—21 世紀モホールを目指して一. 地学雑誌, 117, 110-123.

Arai, S. and Matsukage, K. (1996): Petrology of the gabbro-troctolite-peridotite complex from Hess Deep, equatorial Pacific: Implications for mantlemelt interaction within the oceanic lithosphere. Proceedings of the Ocean Drilling Program, Scientific Results, 147, College Station, TX (Ocean Drilling Program), 135-155.

Arai, S., Matsukage, K., Isobe, E. and Vysotskiy, S. (1997): Concentration of incompatible elements in oceanic mantle: Effect of melt/wall interaction in stagnant or failed melt conduits within peridotite. Geochimica et Cosmochimica Acta, 61, 671-675.

Baba, K., Chave, A.D., Evans, R.L., Hirth, G. and Mackie, R.L. (2006): Mantle dynamics beneath the East Pacific Rise at $17^{\circ} \mathrm{S}$ : Insights from the Mantle Electromagnetic and Tomography (MELT) experiment. Journal of Geophysical Research, 111, B02101, doi:10.1029/2004JB003598.

Barth, G.A. and Mutter, J.C. (1996): Variability in oceanic crustal thickness and structure: Multichannel seismic reflection results from the northern East Pacific Rise. Journal of Geophysical Research, 101, 17951-17975.

Batiza, E. and Vanko, D. (1984): Petrology and magma chamber processes at the East Pacific Rise $9^{\circ} 30^{\prime} \mathrm{N}$. Journal of Geophysical Research, 95, 10801-10827.

Batiza, E., Niu, Y. and Zayac, W.C. (1990): Chemistry of seamounts near the East Pacific Rise: Implications for the geometry of subaxial mantle flow. $G e$ ology, 18, 1122-1125.

Benn, K., Nicolas, A. and Reuber, I. (1988): Mantlecrust transition zone and origin of wehrlitic magmas: Evidence from the Oman ophiolite. Tectonophysics, 151, 75-85.

Boudier, F. and Nicolas, A. (1995): Nature of the Moho transition zone in the Oman ophiolite. Journal of Petrology, 36, 777-796.

Boudier, F., Nicolas, A. and Ildefonse, B. (1996): Magma chambers in the Oman ophiolite: Fed from the top and the bottom. Earth and Planetary Science Letters, 144, 239-250.

Buck, W.R. (2001): Accretional curvature of lithosphere at magmatic spreading centers and the flexural support of axial highs. Journal of Geophysical Research, 106, 3953-3960.
Buck, W.R. and Parmientier, E.M. (1986): Convection beneath young oceanic lithosphre: Implications for thermal structure and gravity. Journal of Geophysical Research, 91, 1961-1974.

Carbotte, S.M., Mutter, J.C. and Xu, L. (1997): Contribution of volcanism and tectonism to axial and flank morphology of the soutehrn East Pacific Rise, $17^{\circ} 10^{\prime} \mathrm{N}-17^{\circ} 40^{\prime} \mathrm{S}$, from a study of layer $2 \mathrm{~A}$ geometry. Journal of Geophysical Research, 102, 1016510184.

Cashman, K.V. and Marsh, B.D. (1988): Crystal size distributions (CSD) in rocks and the kinetics and dynamics of crystallization II: Makaopuhi lava lake. Contributions to Mineralogy and Petrology, 99, 292-305.

Crawford, W.C. and Webb, S.C. (2002): Variations in the distribution of magma in the lower crust and at the Moho beneath the East Pacific Rise at $9^{\circ}-10^{\circ} \mathrm{N}$. Earth and Planetary Science Letters, 203, 117-130.

Crawford, W.C., Webb, S.C. and Hildebrand, J.A. (1999): Constraints on melt in the lower crust and Moho at the East Pacific Rise, $9^{\circ} 48^{\prime} \mathrm{N}$, using seafloor compliance measurements. Journal of Geophysical Research, 104, 2923-2939.

Crisp, J. (1984): Rates of magma emplacement and volcanic output. Journal of Volcanology and Geothermal Research, 20, 177-211.

Crispini, L., Tartarotti, P. and Umino, S. (2006): Microstructural features of a subaqueous lava from basaltic crust off the East Pacific Rise (ODP Site 1256, Cocos Plate). Ofioliti, 31, 117-127.

Donnelly, K.E., Langmuir, C.H. and Goldstein, S.L. (2003): Geochemical constraints on melting proccess in the GLIMPSE region. Eos, Transactions, $A G U, \mathbf{8 4}(46)$, Fall Meeting Supplement, Abstract, V21B-05.

Dunn, R.A. and Toomey, D.R. (1997): Seismological evidence for three-dimensional melt migration beneath the East Pacific Rise. Nature, 388, 259-262.

Dunn, R.A., Toomey, D.R. and Solomon, S.C. (2000): Three-dimensional seismic structure and physical properties of the crust and shallow mantle beneath the East Pacific Rise at $9^{\circ} 30^{\prime}$ N. Journal of Geophysical Research, 105, 23537-23555.

Fornari, D.J., Haymon, R.M., Perfit, M.R., Gregg, T.K.P. and Edwards, M.H. (1998): Axial summit trough of the East Pacific Rise $9^{\circ}-10^{\circ} \mathrm{N}$ : Geological characteristics and evolution of the axial zone on fast spreading mid-ocean ridges. Journal of Geophysical Research, 103, 9827-9856.

Forsyth, D.W., Harmon, N., Scheirer, D.S. and Duncan, R.A. (2006): Distribution of recent volcanism and the morphology of seamounts and ridges in the GLIMPSE study area: Implications for the lithospheric cracking hypothesis for the origin of intraplate, non-hot spot volcanic chains. Journal of Geophysical Research, 111, B11407, doi:10.1029/2005 


\section{JB004075.}

Garmany, J. (1989): Accumulations of melt at the base of young oceanic crust. Nature, 340, 628-633.

Geshi, N., Umino, S., Kumagai, H., Sinton, J.M. White, S.M., Kisimoto, K. and Hilde, T.W. (2007): Discrete plumbing systems and heterogeneous magma sources of a $24 \mathrm{~km}^{3}$ off-axis lava field on the western flank of East Pacific Rise $14^{\circ} \mathrm{S}$. Earth and Planetary Science Letters, 258, 61-72.

Goldstein, S.J., Perfit, M.R., Batiza, R., Fornari, D.J. and Murrell, M.T. (1994): Off-axis volcanism at the East Pacific Rise detected by uranium-series dating of basalts. Nature, 367, 157-159.

Hall, L.S. and Sinton, J.M. (1996): Geochemical diversity of the large lava field on the flank of the East Pacific Rise at $8^{\circ} 17^{\prime}$ S. Earth and Planetary Science Letters, 142, 241-251.

Harding, A.J., Orcutt, J.A., Kappus, M.E., Vera, E.E., Mutter, J.C., Buhl, P., Detrick, R.S. and Brocher, T.M. (1989): Structure of young oceanic crust at $12^{\circ} \mathrm{N}$ on the East Pacific Rise from expanding spread profiles. Journal of Geophysical Research, 94, 12163-12196.

Harding, A.J., Kent, G.M. and Orcutt, J.A. (1993) : A multichannel seismic investigation of upper crustal structure at $9^{\circ} \mathrm{N}$ on the East Pacific Rise: Implications for crustal accretion. Journal of Geophysical Research, 98, 13925-13944.

Harmon, N., Forsyth, D.W. and Scheirer, D.S. (2006): Analysis of gravity and topography in the GLIMPSE study region: Isostatic compensation and uplift of the Sojourn and Hotu Matua Ridge systems. Journal of Geophysical Research, 111, B11406, doi:10. 1029/2005JB004071.

Haxby, W.F. and Weissel, J.K. (1986): Evidence for small scale mantle convection from Seasat altimeter data. Journal of Geophysical Research, 91, 3507-3520.

Hieronymus, C.F. and Bercovici, D. (2000): Non-hotspot formation of volcanic chains: Control of tectonic and flexural stresses on magma transport. Earth and Planetary Science Letters, 181, 539-554.

Hilde, T.W.C. and Kisimoto, K. (2003): Volcanic/tectonic and spatial/temporal relationships of oceanic crustal formation along the Southern East Pacific Rise. Abstract of IUGG 2003, Sapporo, V12/01P/ D-018.

Holmes, R.C., Webb, S.C. and Forsyth, D.W. (2007): Crustal structure beneath the gravity lineations in the Gravity Lineations, Intraplate Melting, Petrologic and Seismic Expedition (GLIMPSE) study area from seismic refraction data. Journal of Geophysical Research, 112, B07316, doi: 10.1029/2006 JB004685.

Hooft, E.E.E., Schouten, H. and Detrick, R.S. (1996): Constraining crustal emplacement processes from the variation in seismic layer $2 \mathrm{~A}$ thickness at the
East Pacific Rise. Earth and Planetary Science Letters, 142, 289-309.

Hooft, E.E.E., Detrick, R.S. and Kent, G.M. (1997): Seismic structure and indicators of magma budget along the southern East Pacific Rise. Journal of Geophysical Research, 102, 27319-27340.

Johnson, K.T.M., Dick, H.J.B. and Shimizu, N. (1990) : Melting in the oceanic upper mantle: An ion microprobe study of diopsides in abyssal peridotites. Journal of Geophysical Research, 95, 2661-2678.

Jousselin, D., Nicolas, A. and Boudier, F. (1998): Detailed mapping of a mantle diapir below a paleospreading center in the Oman ophiolite. Journal of Geophysical Research, 103, 18153-18170.

Jousselin, D., Dunn, R. and Toomey, D.R. (2003): Modeling the seismic signature of structural data from the Oman Ophiolite: Can a mantle diapir be detected beneath the East Pacific Rise? Geochemistry, Geophysics, Geosystems, 4, 8610, doi:10.1029/ 2002 GC000418.

Kelemen, P.B. (1990): Reaction between ultramafic rock and fractionating basaltic magma I. Phase relations, the origin of calc-alkaline magma series, and the formation of discordant dunite. Journal of Petrology, 31, 51-98.

Kelemen, P.B., Shimizu, N. and Salters, V.J.M. (1995): Extraction of mid-ocean ridge basalt from the upwelling mantle by focused flow of melt in dunite channels. Nature, 375, 747-753.

Kelemen, P.B., Koga, K. and Shimizu, N. (1997): Geochemistry of gabbro sills in the crust-mantle transition zone of the Oman ophiolite: Implications for the origin of the oceanic lower crust. Earth and Planetary Science Letters, 146, 475-488.

Kelemen, P.B., Brown, M. and Hirth, G. (2000): Spatial distribution of melt conduits in the mantle beneath oceanic spreading ridges: Observations from Ingals and Oman ophiolites. Geochemistry, Geophysics, Geosystems, 1, doi:10.1029/1999GC000012.

Kent, G.M., Harding, A.J., Orcutt, J.A., Detrick, R.S., Mutter, J.C. and Buhl, P. (1994): Uniform accretion of oceanic crust south of the Garret fransform at $14^{\circ} 15^{\prime} \mathrm{S}$ on the East Pacific Rise. Journal of Geophysical Research, 99, 9097-9116.

岸本清行· Hilde, Thomas, W.C. (1998): [TAMU] ${ }^{2}$ 共 点対画像による海底立体画像と微地形解析の新展開. 1998 年地球惑星科学関連学会合同大会予稿集, 216 .

Kisimoto, K. and Hilde, T.W.C. (2003): In need of combined topography and bathymetry DEM-issues of resolution, consistency and uniformity-2003. EGS-AGU-EUG Joint Assembly 2003, Nice, France, P0176, EAE03-A-07987, TS32-1TH3P-0176.

Korenaga, J. and Jordan, T.H. (2003): Physics of multiscale convection in Earth's mantle: Onset of sublithospheric convection. Journal of Geophysical Research, 108, 2333, doi:10.1029/2002JB001760.

Korenaga, J. and Kelemen, P.B. (1997): Origin of 
gabbro sills in the Moho transition zone of the Oman ophiolite: Implications for magma transport in the oceanic lower crust. Journal of Geophysical Research, 102, 27729-27749.

Llenos, A.L., Forsyth, D.W. and Webb, S.C. (2003): Microearthquakes near Matua Seamount, GLIMPSE study area. EOS, Transactions, AGU, 84(46), Fall Meeting Supplement, Abstract, V12B-0583.

Lupton, J.E. and Craig, H. (1981): A major Helium-3 source at $15^{\circ} \mathrm{S}$ on the East Pacific Rise. Science, 214, 13-18.

Lupton, J.E. and Macdonald, K.C. (1988): Was the South Pacific ${ }^{3} \mathrm{He}$ plume caused by recent eruptions at $8^{\circ} \mathrm{S}$ on the EPR? EOS, Transactions, AGU, 69 488 .

Lynch, M.A. (1999): Linear ridge groups : Evidence for tensional cracking in the Pacific Plate. Journal of Geophysical Research, 104, 29321-29333.

Macdonald, K.C. and Fox, P.J. (1988): The axial summit graben and cross-sectional shape of the East Pacific Rise as indicators of axial magma chambers and recent volcanic eruptions. Earth and Planetary Science Letters, 88, 119-131.

Macdonald, K.C., Haymon, R. and Shor, A. (1989): A $220 \mathrm{~km}^{2}$ recently erupted lava field on the East Pacific Rise near lat $8^{\circ} \mathrm{S}$. Geology, 17, 212-216.

Maclennan, J., Hulme, T. and Singh, S.C. (2005): Cooling of the lower oceanic crust. Geology, 33, 357-360.

MacLeod, C.J. and Yaouancq, G. (2000): A fossil melt lens in the Oman ophiolite: Implications for magma chamber processes at fast spreading ridges. Earth and Planetary Science Letters, 176, 357-373.

Magde, L.S. and Smith, D.K. (1995): Seamount volcanism at the Reykjanes Ridge: Relationship to the Iceland hot spot. Journal of Geophysical Research, 100, 8449-8468.

Mahoney, J.J., Sinton, J.M., Kurz, M.D., Macdougall, J.D., Spencer, K.J. and Lugmair, G.W. (1994): Isotope and trace element characteristics of a superfast spreading ridge: East Pacific rise, $13-23^{\circ} \mathrm{S}$. Earth and Planetary Science Letters, 121, 173-193.

松本 剛 - 宮下純夫 - 荒井章司 - 森下知晃 - 前田仁一 郎・熊谷英憲・大友幸子·Dick, Henry J.B. (2003)： 南西インド洋海嶺アトランティス海台に見られる超 低速拡大軸の火成活動と「地殼・マントル境界」。地 学雑誌, 112, 705-719.

Nicolas, A. (1989): Structures of Ophiolites and Dynamics of Oceanic Lithosphere. Kluwer Academic Publishers, Dordrecht, 367p.

Nicolas, A., Boudier, F. and Ildefonse, B. (1996): Variable crustal thickness in the Oman ophiolite: Implication for oceanic crust. Journal of Geophysical Research, 101, 17941-17950.

Niu, Y. and Batiza, E. (1997): Trace element evidence from seamounts for recycled oceanic crust in the Eastern Pacific mantle. Earth and Planetary
Science Letters, 148, 471-483.

小澤一仁 (2005): 上部マントルにおけるマグマの形成 過程：マントル物質科学における近年の展開. 地学 雑誌, 114, 385-409.

小澤一仁 (2008): 海洋モホ面形成におけるダナイトの 役割. 地学雑誌, 117, 146-167.

Perfit, M.R. and Chadwick, Jr., W.W. (1998): Magmatism at mid-ocean ridges: Constraints from volcanological and geochemical investigations. in Faulting and Magmatism at Mid-Ocean Ridges edited by Buck, W.R., Delaney, P.T., Karson, J.A. and Lagabrielle, Y., AGU Geophysical Monograph, 106, 59-116.

Perfit, M.R., Fornari, D.J., Smith, M.C., Bender, J.F., Langmuir, C.H. and Haymon, R.M. (1994): Smallscale spatial and temporal variations in mid-ocean ridge crest magmatic processes. Geology, 22, 375379.

Perrot, K., Francheteau, J., Maia, M. and Tisseau, C. (1998): Spatial and temporal variations of subsidence of the East Pacific Rise $\left(0-23^{\circ} \mathrm{S}\right)$. Earth and Planetary Science Letters, 160, 593-607.

Pyle, D.M. (2000): Sizes of volcanic eruptions. in Encyclopedia of Volcanoes edited by Sigurdsson, H., Houghton, B.F., McNutt, S.R., Rymer, H. and Stix, J., Academic Press, San Diego, 263-269.

Rappaport, Y., Naar, D.F., Barton, C.C., Liu, Z.J. and Hey, R.N. (1997): Morphology and distribution of seamounts surrounding Easter Island. Journal of Geophysical Research, 102, 24713-24728.

Reynolds, J.R. and Langmuir, C.H. (2000): Identification and implications of off-axis lava flows around the East Pacific Rise. Geochemistry, Geophysics, Geosystems, 1, doi:10.1029/1999GC 000033.

Reynolds, J.R., Langmuir, C.H., Bender, J.F., Kastens, K.A. and Ryan, W.B.F. (1992): Spatial and temporal variability in the geochemstry of basalts from the East Pacific Rise. Nature, 359, 493-499.

Sandwell, D.T. and Fialko, Y. (2004): Warping and cracking of the Pacific plate by thermal contraction. Journal of Geophysical Research, 109, doi:10.1029/ 2004JB003091.

Sandwell, D.T., Winterer, E.L., Mammerickx, J., Duncan, R.A., Lynch, M.A., Levitt, D.A. and Johnson, C.L. (1995): Evidence for diffuse extension of the Pacific plate from Pukapuka ridges and cross-grain gravity lineations. Journal of Geophysical Research, 100, 15087-15099, doi:10.1029/2004JB003091.

Scheirer, D.S. and Macdonald, K.C. (1993) : Variation in cross-sectional area of the axial ridge along the East Pacific Rise: Evidence for the magmatic budget of a fast spreading center. Journal of Geophysical Research, 98, 7871-7885.

Scheirer, D.S., Macdonald, K.C., Forsyth, D.W. and Shen, Y. (1996): Abundant seamounts of the Rano Rahi seamount field near the Southern East Pacific Rise, $15^{\circ} \mathrm{S}$ to $19^{\circ} \mathrm{S}$. Marine Geophysical Researches, 
18, $13-52$.

Scheirer, D.S., Forsyth, D.W., Cormier, M.-H. and Macdonald, K.C. (1998): Shipboard geophysical indications of asymmetry and melt production beneath the East Pacific Rise near the MELT experiment. Science, 280, 1221-1224.

Shaw, D.M. (1970): Trace element fractionation during anatexis. Geochimica et Cosmochimica Acta, 34, 237-243.

Sims, K.W.W., Blichert-Toft, J., Fornari, D.J., Perfit, M.R., Goldstein, S.J., Johnson, P., DePaolo, D.J., Hart, S.R., Murrell, M.T., Michael, P.J., Layne, G.D. and Ball, L.A. (2003): Aberrant youth: Chemical and isotopic constraints on the origin of off-axis lavas from the East Pacific Rise, $9^{\circ}-10^{\circ}$ N. Geochemis try, Geophysics, Geosystems, 4, 8621, doi:10.1029/ 2002GC000443.

Singh, S.C., Kent, G.M., Collier, J.S., Harding, A.J., and Orcutt, J.A. (1998): Melt to mush variations in crustal magma properties along the ridge crest at the southern East Pacific Rise. Nature, 394, 874878.

Sinton, J.M. and Detrick, R.S. (1992): Mid-ocean ridge magma chambers. Journal of Geophysical Research, 97, 197-216.

Sinton, J.M., Bergmanis, E., Rubin, K., Batiza, R., Gregg, T.K.P., Grönvold, K., Macdonald, K.C. and White, S.M. (2002): Volcanic eruptions on midocean ridges: New evidence from the superfast spreading East Pacific Rise, $17^{\circ}-19^{\circ} \mathrm{S}$. Journal of Geophysical Research, 107, doi:10.1029/200JB 000090.

Smith, D.K. and Cann, J.R. (1992): The role of seamount volcanism in crustal construction at the Mid-Atlantic Ridge $\left(24^{\circ}-30^{\circ} \mathrm{N}\right)$. Journal of Geophysical Research, 97, 1645-1658.

Smith, D.K. and Jordan, T.H. (1987): The size distribution of Pacific seamounts. Geophysical Research Letters, 14, 1119-1122.

Smith, D.K. and Jordan, T.H. (1988): Seamount statistics in the Pacific Ocean. Journal of Geophysical Research, 93, 2899-2918.

Smith, D.K., Cann, J.R., Dougherty, M.E., Lin, J., Spencer, S., MacLeod, C., Keeton, J., McAllister, E., Brooks, B., Pascoe, R. and Robertson, W. (1995): Mid-Atlantic Ridge volcanism from deep-towed side-scan sonar images, $25^{\circ}-29^{\circ}$ N. Journal of Volcanology and Geothermal Research, 67, 233-262.

Smith, W.H.F. and Sandwell, D.T. (1997): Global seafloor topography from satellite altimetry and ship depth soundings. Science, 277, 1957-1962.

Sohn, R.A. and Sims, K.W.W. (2005): Bending as a mechanism for triggering off-axis volcanism on the East Pacific Rise. Geology, 33, 93-96.

Spiegelman, M. and McKenzie, D. (1987): Simple 2-D models for melt extraction at mid-ocean ridges and island arcs. Earth and Planetary Science Let- ters, 83, 137-152.

Spiegelman, M. and Reynolds, J.R. (1999): Combined dynamic and geochemical evidence for convergent melt flow beneath the East Pacific Rise. Nature, 402, 282-285.

Teagle, D.A.H., Alt, J.C., Umino, S., Miyashita, S., Banerjee, N.R., Wilson, D.S. and the Expedition 309/312 Scientists (2006): Proceedings of the Integrated Ocean Drilling Program, 309/312, Washington, DC (Integrated Ocean Drilling Program Management International, Inc.), doi:10.2204/iodp.proc. 309312.101.2006.

Thordarson, T.H. and Self, S. (1998) : The Roza Member, Columbia River Basalt Group: A gigantic pahoehoe lava flow field formed by endogenous processes? Journal of Geophysical Research, 103, 27411-27446.

Toomey, D.R., Purdy, G.M., Solomon, S.C. and Wilcock, W.S.D. (1990): The three-dimensional seismic velocity structure of the East Pacific Rise near latitude $9^{\circ} 30^{\prime} \mathrm{N}$. Nature, 347, 639-645.

上杉次郎 - 荒井章司 - 森下知晃 - 松影香子 - 角島和之 田村明弘・阿部なつ江 (2003): オマーンオフィオラ イトにおけるマントルー地殼境界の実体と多様性. 地 学雑誌, 112, 750-768.

Umino, S. (2006): Contrasting upper crustal structures revealed by deep ocean crust drilling - Insights into shallow magma plumbing systems beneath intermediate versus superfast spreading ridges. Abstract of the 19th General Meeting of International Mineralogical Association, Kobe, 90348.

Umino, S. (2007): Data Report: Textural variation of Units $1256 \mathrm{C}-18$ and 1256D-1 lava pond, with special reference to recrystallization of the base of Unit 1256C-18 (PDF). in Proceedings of the Ocean Drilling Program, Scientific Results edited by Teagle, D.A.H., Wilson, D.S., Acton, G.D. and Vanko, D.A., 206, College Station, TX (Ocean Drilling Program), 1-32, doi:10.2973/odp.proc.sr.206.007.2007.

海野 進 ·下司信夫 · Hilde, Thomas W.C. · 岸本清行 · 熊谷英憲・Sinton, John M. • White, Scott M. (2004): 東太平洋海膨 $14^{\circ} \mathrm{S}$ で発見された巨大海底溶岩流— NIRAI-KANAI Cruise Leg 1, YK04-07 よこすか一し んかい潜航調査結果速報. 日本火山学会講演予稿集 2004 年度秋季大会, 28 .

Vera, E.E., Mutter, J.C., Buhl, P., Orcutt, J.A., Harding, A.J., Kappus, M.E., Detrick, R.S. and Brocher, T.M. (1990): The structure of 0 to 0.2 m.y. old oceanic crust at $9^{\circ} \mathrm{N}$ on the East Pacific Rise from expanded spread profiles. Journal of Geophysical Research, 95, 15529-15556.

White, S.M., Macdonald, K.C., Scheirer, D.S. and Cormier, M.-H. (1998): Distribution of isolated volcanoes on the flanks of the East Pacific Rise, $15.3^{\circ}-20^{\circ}$ S. Journal of Geophysical Research, 103, 30371-30384.

White, S.M., Macdonald, K.C. and Sinton, J.M. (2002): 
Volcanic mound fields and lava flow fields on the East Pacific Rise, $16^{\circ}-19^{\circ} \mathrm{S}$ : Low Effusion Rate Eruptions at Overlapping Spreading Centers for the Last 1 Myr. Journal of Geophysical Research, 107, doi:10.1029/2001JB000483.

White, S.M., Umino, S. and Kumagai, H. (2006): Transition from seamount chain to intra-plate volcanic ridge at the East Pacific Rise. Geology, 34, 293-296.

Wilson, D.S. (1996): Fastest known spreading on the Miocene Cocos-Pacific plate boundary. Geophysical Research Letters, 23, 3003-3006.

Wilson, D.S., Teagle, D.A.H., Acton, G.D. et al. (2003): Proceedings of the Ocean Drilling Program, Initial Reports, 206 [CD-ROM]. Available from: Ocean Drilling Program, Texas A\&M University, College Station TX 77845-9547, USA.

Wilson, D.S., Teagle, D.A.H., Alt, J.C., Banerjee, N.R.,
Umino, S., Miyashita, S., Acton, G.D., Anma, R., Barr, S.R., Belghoul, A., Carlut, J., Christie, D.M., Coggon, R.M., Cooper, K.M., Cordier, C., Crispini, L., Durand, S.R., Einaudi, F., Galli, L., Gao, Y., Geldmacher, J., Gilbert, L.A., Hayman, N.W., Herrero-Bervera, E., Hirano, N., Holter, S., Ingle, S., Jiang, S., Kalberkamp, U., Kerneklian, M., Koepke, J., Laverne, C., Haroldo, L., Lledo Vasquez, Maclennan, J., Morgan, S., Neo, N., Nichols, H.J., Park, S.-H., Reichow, M.K., Sakuyama, T., Sano, T., Sandwell, R., Scheibner, B., Smith-Duque, C.E., Swift, S.A., Tartarotti, P., Tikku, A.A., Tominaga, M., Veloso Espinosa, E.A., Yamasaki, T., Yamazaki, S. and Ziegler, C. (2006): Drilling to gabbro in intact ocean crust. Science, 312, 1016-1020.

(2007 年 10 月 17 日受付, 2008 年 1 月 19 日受理) 